\title{
Review
}

\section{Recent Advances in Biomass Pretreatment Technologies for Biohydrogen Production}

\author{
Harshita Singh ${ }^{1}$, Sakshi Tomar ${ }^{1}$, Kamal A. Qureshi ${ }^{1,2}{ }^{1}$, Mariusz Jaremko ${ }^{3}$ and Pankaj K. Rai ${ }^{1, *}$ \\ 1 Department of Biotechnology, Faculty of Biosciences, Invertis University, Bareilly 243123, India; \\ singh.harshita12@gmail.com (H.S.); sakshitomar1230@gmail.com (S.T.); ka.qurishe@qu.edu.sa (K.A.Q.) \\ 2 Department of Pharmaceutics, Unaizah College of Pharmacy, Qassim University, \\ Unaizah 51911, Saudi Arabia \\ 3 Smart-Health Initiative (SHI) and Red Sea Research Center (RSRC), Division of Biological and Environmental \\ Sciences and Engineering (BESE), King Abdullah University of Science and Technology (KAUST), \\ Thuwal 23955, Saudi Arabia; mariusz.jaremko@kaust.edu.sa \\ * Correspondence: pankaj.r@invertis.org; Tel.: +91-945-255-0100
}

Citation: Singh, H.; Tomar, S.; Qureshi, K.A.; Jaremko, M.; Rai, P.K. Recent Advances in Biomass Pretreatment Technologies for Biohydrogen Production. Energies 2022, 15, 999. https://doi.org/ $10.3390 /$ en15030999

Academic Editor: Dmitri A. Bulushev

Received: 4 November 2021

Accepted: 7 January 2022

Published: 29 January 2022

Publisher's Note: MDPI stays neutral with regard to jurisdictional claims in published maps and institutional affiliations.

Copyright: (C) 2022 by the authors. Licensee MDPI, Basel, Switzerland. This article is an open access article distributed under the terms and conditions of the Creative Commons Attribution (CC BY) license (https:// creativecommons.org/licenses/by/ $4.0 /)$.

\begin{abstract}
Hydrogen is an economical source of clean energy that has been utilized by industry for decades. In recent years, demand for hydrogen has risen significantly. Hydrogen sources include water electrolysis, hydrocarbon steam reforming, and fossil fuels, which emit hazardous greenhouse gases and therefore have a negative impact on global warming. The increasing worldwide population has created much pressure on natural fuels, with a growing gap between demand for renewable energy and its insufficient supply. As a result, the environment has suffered from alarming increases in pollution levels. Biohydrogen is a sustainable energy form and a preferable substitute for fossil fuel. Anaerobic fermentation, photo fermentation, microbial and enzymatic photolysis or combinations of such techniques are new approaches for producing biohydrogen. For cost-effective biohydrogen production, the substrate should be cheap and renewable. Substrates including algal biomass, agriculture residue, and wastewaters are readily available. Moreover, substrates rich in starch and cellulose such as plant stalks or agricultural waste, or food industry waste such as cheese whey are reported to support dark- and photo-fermentation. However, their direct utilization as a substrate is not recommended due to their complex nature. Therefore, they must be pretreated before use to release fermentable sugars. Various pretreatment technologies have been established and are still being developed. This article focuses on pretreatment techniques for biohydrogen production and discusses their efficiency and suitability, including hybrid-treatment technology.
\end{abstract}

Keywords: biohydrogen; feedstock; fermentation; fossil fuel; global warming; substrate pretreatment

\section{Introduction}

Currently, the world is facing severe energy problems. Global energy demands have been met through the use of non-renewable energy sources. Excessive burning of fossil fuels has caused global climate change with disastrous effects. Biohydrogen could strategically serve as an alternative to non-renewable energy because it is a clean energy carrier with low emissions. It is renewable, clean, has high energy content, and does not contribute to the accumulation of greenhouse gases (GHGs) [1]. Due to its eco-friendly nature, hydrogen production through biological processes utilizing biomass is one of the most remarkable techniques [2]. Anaerobic fermentation processes are desirable since hydrogen production is enhanced and obtained from organic wastes or sewage water emended with carbohydrates as substrate. The rate of production of biohydrogen depends upon the kind of substrates and conversion technologies utilized. It is imperative to use lowcost substrates such as glycerol, glucose, and cellulose for cost-effective biohydrogen production [3]. Identifying and selecting sustainable fuels derived from biomass is the most promising option for sustainable energy generation. Biomass from industries and 
algae could be a viable source for biohydrogen production, especially in cases where waste treatment and energy production are combined (Table 1).

Table 1. Biohydrogen production using various substrates.

\begin{tabular}{ccc}
\hline Substrates & $\mathbf{H}_{\mathbf{2}}$ Yield & References \\
\hline Olive mill wastewater & $13.9 \mathrm{~L} \mathrm{H}_{2} / \mathrm{L} \mathrm{OMW}$ & {$[4]$} \\
Chlamydomonas reinhardtii & $311.1 \mathrm{~mL} \mathrm{H}_{2} / \mathrm{g} \mathrm{monosaccharides}$ & {$[5]$} \\
Dairy Wastewater & $3.6 \mathrm{~L} \mathrm{H}_{2} / \mathrm{L} \mathrm{dairy} \mathrm{wastewater}$ & {$[6]$} \\
Arthrospira platensis & $337.0 \mathrm{~mL} \mathrm{H}_{2} / \mathrm{g} \mathrm{DW}$ & {$[7]$} \\
Microalgae & $25.1 \mathrm{~mL} \mathrm{H}_{2} / \mathrm{g} \mathrm{dry} \mathrm{biomass} \mathrm{powder}^{[8]}$ & {$[9]$} \\
Cheese whey & $2.04 \mathrm{~mol} \mathrm{H}_{2} / \mathrm{mol} \mathrm{lactose}$ & {$[10]$} \\
\hline
\end{tabular}

Note: DW: Dry weight; MW: Olive mill wastewater.

Carbohydrate-rich, nitrogen-deficient solid waste such as starch residues may be used for hydrogen production using suitable bioprocess technologies. Sugarcane bagasse is the most readily available fibrous material obtained after juice extraction from cane. In most cases, sugarcane bagasse is discarded or fed into mill boilers, neither of which is beneficial to the long-term use of resources and the environment. Sugarcane bagasse contains high cellulose, hemicellulose, and lignin, making it a suitable substrate for producing value-added chemicals and fuels via a biorefinery approach. Because of the complicated structure of cellulose present in bagasse, pretreatment is carried out to improve enzymatic hydrolysis. Thus, substrate pretreatment is essential before it is subjected to hydrolysis or fermentation [3].

Algal biomass can be used as a substrate for biohydrogen production. The utilization of algal biomass has dual benefits as algae sequestered carbon dioxide, which contributes towards the global reduction of harmful greenhouse gases concerning climatic changes, and secondly, it releases oxygen [3]. Substrate pretreatment is one of the significant steps in the successful utilization of biomass for biohydrogen production. Sometimes, the pretreatment of the inoculum also enhances the rate and yield of the biohydrogen. The pretreatment of anaerobic sewage sediment by various methods such as acid, alkali, chloroform, heatshock, ethylenediaminetetraacetic acid (EDTA), ammonia, ozonolysis, and microwave were carried out in batch experiments to test and compare their hydrogen-producing efficiency utilizing various sources of carbon. Among the various pretreatment methods, heat-shock and base treatment showed more $\mathrm{H}_{2}$ generation at $35^{\circ} \mathrm{C}$ and $6.5 \mathrm{pH}$ using $5 \mathrm{~g} / \mathrm{L}$ substrate concentration. The combined action of base and heat pretreatment was found to be the most suitable method for efficient hydrogen production [11]. Several other methods have been reported to enhance hydrogen yield in the recent past through mutation, genetic manipulation, metabolic engineering, and optimization of substrates' pretreatments [3]. In the future, due attention must be paid to identifying optimal conditions and suitable techniques for substrates' pretreatments for cost-effective biohydrogen. The overview of various pretreatment methods employed for efficient biohydrogen production is summarized in (Figure 1). This review focuses on technologies used for pretreatment of substrate and inoculum for biohydrogen production, discussing their advantages and disadvantages.

\subsection{Algae Biomass-Based Biohydrogen Production}

Algae can be either prokaryotic or eukaryotic, performing photosynthesis such as higher plants and contributing to approximately 50\% of global carbon fixation depending on the amount of light captured and photosynthesis [8,12]. Algal carbohydrates constitute $15-70 \%$ of dry cell mass and have a unique basic composition in every algal strain. As algae are rich in proteins, free amino acids can be obtained by hydrolysis of proteins. The cultivation medium and environment also affect the composition of the algal biomass. The cultivation of $N$. oleobundans in freshwater raises the carbohydrate content of the cell wall, whereas glucose content rises when grown in seawater [13]. Arthrospira platensis total carbohydrate content was reported to be $64.3 \%$, mainly in the form of glucan [7]. The 
$\alpha$-glucan is made up primarily of glucose (>90\%), with negligible other simple sugars [14]. To obtain useful raw material to produce biohydrogen, suitable pretreatment must be used to extract both structural and storage microalgal carbohydrates from biomass after harvesting [15].

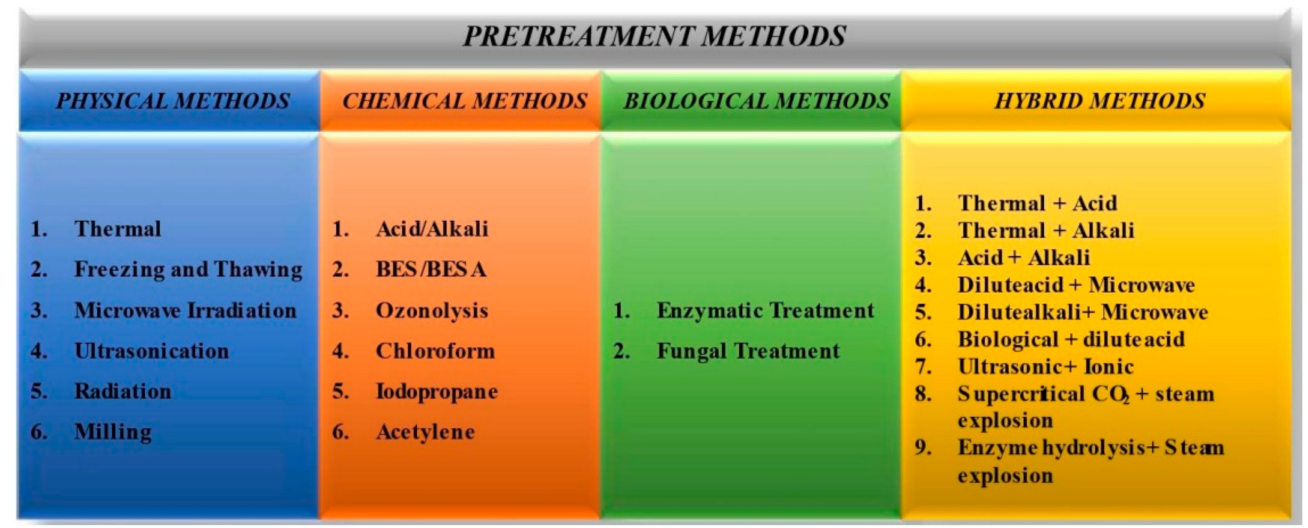

Figure 1. Schematic representation of various pretreatment methods.

Pretreatment is obligatory for releasing fermentable sugars from algal biomass, as hydrogen-producing bacteria (HPB) typically have less hydrolytic enzymatic activity. To improve the efficiency of the fermentative biohydrogen production from algal biomass, pretreatment is imperative to liberate simple fermentable sugars from complex substrates and make them readily biodegradable. Methods employed for algal biomass pretreatment are physical (mechanical, heat, microwave irradiation, and ultrasonic treatment), chemical (acid, alkali, chloroform, ozonolysis), and biological (enzymatic treatment). These pretreatment methods are supposed to break down the cell wall and facilitate organic substances to be released from the cells [12]. After appropriate pretreatment, the HPB could consume simple substrates to produce hydrogen.

The production of biohydrogen primarily requires algae with high carbohydrate content. To avoid carbohydrate loss during pretreatment processes, the pretreatment method should be chosen very carefully, keeping in mind energy, environmental and economic indicators to achieve maximum efficiency with maximum hydrogen yield. Before selecting a pretreatment method for algal biomass, the following factors should be considered [15]. The efficiency of the pretreatment method is one of the major factors, depending in part on cell disruption efficiency and product yield. Energy demand is also important, as mechanical methods have high energy demands. Hence, to reduce the energy demand and improve performance, a combination of chemical and thermal processes may be used in combination with mechanical methods. Such an approach may reduce environmental impact. Cost is also an important factor. Microwaves or pulsed electric fields have high associated costs, while continuous systems with wet microalgal biomass may reduce costs by eliminating drying and dewatering processes. Product quality is another relevant factor. Although the selected pretreatment method should not ideally influence the quality of the product, it may be compromised in methods involving cavitation or oxidation, where free radicals are generated, or in chemical pretreatment, where excess salts are produced due to neutralization reactions. Another factor is the pollution generated from the solvents used in chemical pretreatment methods [10]. Specific criteria should be followed for selecting the pretreatment technology; the chosen approach should avoid biomass size reduction; the proportion of hemicellulose must be conserved and should be less energy-intensive [16].

\subsection{Substrates for Biohydrogen Production and Their Pretreatment}

Various pretreatment strategies have been studied to use waste materials for biohydrogen production. Pretreatment of the substrate is essential for efficient bio-hydrogen production. Pretreatment facilitates the substrate breakdown into simple sugars, a prerequi- 
site for microbial growth. Fermentation at high operating temperatures $\left(65-70^{\circ} \mathrm{C}\right)$ improves the substrate degradation rate and thus increases $\mathrm{H}_{2}$ production rate [17]. Various wastes or wastewaters, such as olive mill effluent [4], are ideal for photo-biological $\mathrm{H}_{2}$ production as they contain ethanol, acetate, butyrate, and propionate. Sewage sludge and tofu wastewater are regarded as the most promising substrates for the production of $\mathrm{H}_{2}$. Before being utilized as a substrate, sewage sludge is pretreated for $1 \mathrm{~h}$ at $150{ }^{\circ} \mathrm{C}$ temperature under $10 \mathrm{~atm}$ after alkali treatment. During photo-fermentation, $0.17-0.28 \mathrm{~L} \mathrm{H}_{2} / \mathrm{L}$ broth/day is constantly produced [18]. Cassava pulp is a by-product of the starch industry that contains up to $60 \%$ starch as dry matter and contains carbohydrates, including cellulose and hemicelluloses. Cassava pulp's cellulose and hemicellulose may be acid hydrolyzed and utilized as a substrate for fermentative hydrogen production by anaerobic mixed cultures, under optimum hydrolysis conditions; $0.5 \% \mathrm{H}_{2} \mathrm{SO}_{4}$ at a ratio of $1: 15$ (dry $w / v$ ) for $30 \mathrm{~min}$, resulting in $27.4 \mathrm{~g} / \mathrm{L}$ of total sugar yield [14]. Using various organic-rich domestic, agricultural, and industrial waste products for biohydrogen production decreases the cost of scaling up while also effectively removing the organic load [19]. Cheese whey is an excellent substrate for fermentative $\mathrm{H}_{2}$ generation since it comprises $4.6 \%$ lactose, $1.2 \%$ crude protein, $0.6 \%$ ash, $0.3 \%$ fat, $5-8 \%$ total solids, and $92.7 \%$ water $[9,10]$. Dairy wastewaters contain polysaccharides, proteins, and lipids, which undergo hydrolysis to sugars, amino acids, and fatty acids [18]. During fermentation, they are transformed into volatile fatty acids (VFAs), which are then degraded by acetogens to produce acetate, $\mathrm{CO}_{2}$, and $\mathrm{H}_{2}$ [20]. Pretreatment of complex biomass containing lignocelluloses is prevalent, as most complex substrates are unsuitable and must be broken down into simple components for easier access during fermentation [21] (Figure 2).

After selecting a microbial consortium enriched in hydrogen-producing ability, the accessibility of easily decomposable substrate is essential for the growth of microbes and hydrogen production. Algal biomass is enriched in large sugar residues and is considered an ideal substrate for $\mathrm{H}_{2}$ production [22]. Algal biomass (such as other organic waste) can be used for $\mathrm{H}_{2}$ generation due to its high protein, fat, and carbohydrate content $[5,14]$. Nguyen et al. (2010) used accumulated starch present within the green algae C. reinhardtii as a substrate. Later, the hyperthermophilic eubacterium T. neapolitana was used to convert that accumulated starch into $\mathrm{H}_{2}$ gas [5]. The algal starch could be directly fermented into $\mathrm{H}_{2}$ by a bacterium with amylase activity $\left(1.8-2.2 \mathrm{~mol} \mathrm{H}_{2} / \mathrm{mol}\right)$ [22]. These wastes' cellulose and hemicellulose percentages must be hydrolyzed to degrade carbohydrates to achieve high $\mathrm{H}_{2}$ production. The resultant treated waste may be regarded as the potential substrate for fermentative hydrogen production. The main purpose of substrate pretreatment technology is to break down the complex structure of less degradable organic compounds and improve their solubility, thereby upgrading $\mathrm{H}_{2}$ yield. The type of substrate and pretreatment method used may affect the yield of hydrogen and the characteristics of the effluents. Ideally, the best substrate pretreatment method should be selected, with high hydrogen yield, cost efficiency, process sustainability, and low energy requirements.

\subsection{Inoculum Pretreatment}

Inoculum pretreatment technologies are also utilized to enhance the $\mathrm{H}_{2}$ production yield (Figure 3). These pretreatment technologies help to improve $\mathrm{H}_{2}$ yield by suppressing the hydrogen-consuming bacteria $(\mathrm{HCB})$ and methane production. Inoculum pretreatment is proven to select micro-flora for better hydrogen production [23] (Table 2). Many studies have reported that pretreatment of sludge to avoid methane production and suppress the action of HCB leads to higher $\mathrm{H}_{2}$ production [24-27]. Pretreatment of inoculum or substrate may result in enhanced hydrogen content in the range of $43-69 \%$ [28]. Pretreatment of anaerobic inoculum accelerates hydrolysis, reducing the effect of the rate-limiting step and improving process stability, thus enhancing anaerobic digestion for effective $\mathrm{H}_{2}$ production [29-31]. Various inoculum pretreatment methods exist to enhance hydrogen production, including heat pretreatment, acid/alkali-treatment, ultrasonic waves, chloroform, and iodopropane $[23,29,30]$. Among these methods, the first three are more effective. 
Pretreatment steps vary, depending on the inoculum and substrate utilized and their unique properties that affect the $\mathrm{H}_{2}$ yield.

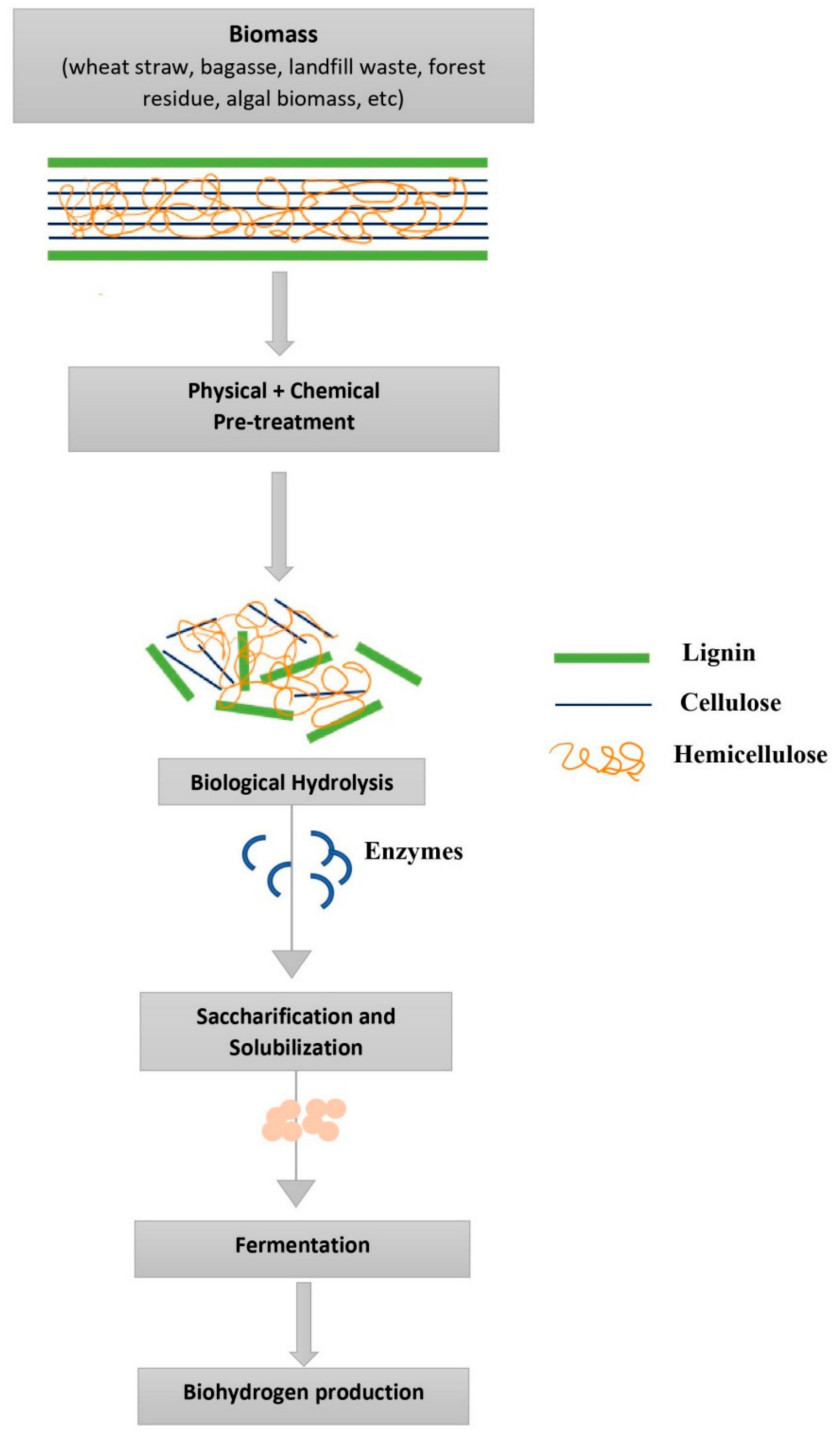

Figure 2. Schematic representation of biomass hydrolysis for biofuel production using physical, chemical, and biological pretreatment methods.

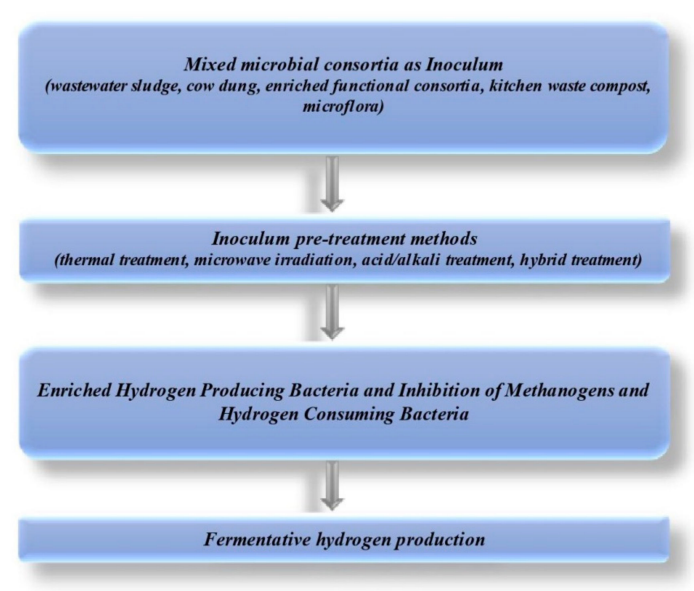

Figure 3. Inoculum pretreatment approaches for biohydrogen production by mixed microbial culture. 
Table 2. List of various substrate pretreatment methods used for biohydrogen production.

\begin{tabular}{|c|c|c|c|c|c|}
\hline Substrate & Pretreatment & Pretreatment Conditions & Hydrogen Yield & $\begin{array}{c}\text { Increase in } \mathrm{H}_{2} \\
\text { Yield (\%) }\end{array}$ & References \\
\hline Rice mill wastewater & Thermal & $\begin{array}{l}121^{\circ} \mathrm{C} \text { temp } \\
\text { Time: } 15 \mathrm{~min}\end{array}$ & $\begin{array}{l}\text { Control: } 90 \mathrm{~mL} \\
\text { of hydrogen } \\
\text { Pretreated: } 200 \mathrm{~mL} \\
\text { of hydrogen }\end{array}$ & 55 & [32] \\
\hline $\begin{array}{l}\text { Beetroot } \\
\text { pulp }\end{array}$ & Microwave & $\begin{array}{l}700 \mathrm{~W} ; 170^{\circ} \mathrm{C} \text { temp } \\
\text { Time: } 30 \mathrm{~min}\end{array}$ & $\begin{array}{l}\text { Control: } 95.7 \mathrm{~mL} \\
\text { of hydrogen } \\
\text { Pretreated: } 108.7 \mathrm{~mL} \\
\text { of hydrogen }\end{array}$ & 12 & [33] \\
\hline $\begin{array}{c}\text { Palm oil } \\
\text { mill effluent (POME) }\end{array}$ & Acid & $\begin{array}{c}0.8 \%(w / v) \text { phosphoric } \\
\text { acid and } 1 \%(w / v) \\
\text { nitric acid. } \\
\text { Time: } 10 \mathrm{~min}\end{array}$ & $\begin{array}{c}\text { Control: } 0.64 \mathrm{~mol} \mathrm{H}_{2} / \mathrm{mol} \\
\text { Pretreated: } 1.24 \mathrm{~mol} \\
\mathrm{H}_{2} / \mathrm{mol}\end{array}$ & 48.4 & [34] \\
\hline $\begin{array}{l}\text { Bio-methenated } \\
\text { distillery wastewater }\end{array}$ & Ozone & $\begin{array}{l}\text { Ozone dose: } 4.6 \mathrm{~g} / \mathrm{h} \\
\text { Time: } 160 \mathrm{~min}\end{array}$ & $\begin{array}{c}\text { Control: } 0.37 \mathrm{~mL} / \mathrm{h} \text { of } \\
\text { hydrogen yield with } \\
44.19 \mathrm{~mL} / \mathrm{g} \mathrm{COD} \\
\text { Pretreated: } 1.18 \mathrm{~mL} / \mathrm{h} \text { of } \\
\mathrm{H}_{2} \text { yield with } \\
185.5 \mathrm{~mL} / \mathrm{g} \mathrm{COD}\end{array}$ & 68.6 & [35] \\
\hline Cassava wastewater & Enzymatic & $\begin{array}{c}\alpha \text {-amylase (Incubation } \\
\text { temperature: } 37^{\circ} \mathrm{C} \text { ) } \\
\text { OPTIMASH BG }{ }^{\circledR} \\
\text { (Incubation temperature: } \\
60^{\circ} \mathrm{C} \text { ) } \\
\text { Incubation period: } 10 \text { day }\end{array}$ & $\begin{array}{c}\text { Control: } 2.06 \mathrm{~mol} / \mathrm{g} \mathrm{COD} \\
\text { Pretreated: } 5.02 \mathrm{~mol} / \mathrm{g} \\
\text { COD }(\alpha \text {-amylase }) \\
4.24 \mathrm{~mol} / \mathrm{g} \text { COD } \\
(\mathrm{OPTIMASH} \\
\left.\mathrm{BG}^{\circledR}\right)\end{array}$ & $\begin{array}{l}58.9 \\
51.4\end{array}$ & [36] \\
\hline Rice mill wastewater & $\begin{array}{c}\text { Combined } \\
\text { (acid followed by } \\
\text { enzymatic) }\end{array}$ & $\begin{array}{c}\text { Acid - } 1.5 \% \mathrm{H}_{2} \mathrm{SO}_{4} \\
\text { Reaction time: } 60 \mathrm{~min} \\
\text { Enzyme: } A \text {. niger } \\
\text { Incubation temperature: } \\
29^{\circ} \mathrm{C}\end{array}$ & $\begin{array}{l}\text { Control: } 0.128 \mathrm{~mol} / \mathrm{L} \\
\text { of hydrogen } \\
\text { Pretreated: } 5.34 \mathrm{~mol} / \mathrm{L} \\
\text { of hydrogen. }\end{array}$ & 97.6 & [37] \\
\hline $\begin{array}{l}\text { Textile desizing } \\
\text { wastewater }\end{array}$ & $\begin{array}{c}\text { Combined } \\
\text { pretreatment } \\
\text { (flocculation and } \\
\text { coagulation) }\end{array}$ & $\begin{array}{c}\text { Coagulant } \\
\text { GGEFloc-653 }-1 \mathrm{~g} / \mathrm{L} \\
\text { Rapid mixing } 100 \mathrm{rpm} \\
(3 \mathrm{~min}), \text { Slow mixing } \\
30 \mathrm{rpm} \\
(20 \mathrm{~min}) \text {, Sludge settling } \\
\text { time: } 1 \mathrm{~h}\end{array}$ & $\begin{array}{l}\text { Control: } 0.88 \mathrm{~L} / \mathrm{L}-\mathrm{d} \mathrm{H} \mathrm{H}_{2} \\
\text { production rate } \\
\text { Pretreated: } 3.8 \mathrm{~L} / \mathrm{L}-\mathrm{d} \mathrm{H}_{2} \\
\text { production rate }\end{array}$ & 76.8 & [38] \\
\hline
\end{tabular}

\section{Pretreatment Technologies}

Various pretreatment methods for biomass and inoculum pretreatment, and their advantages and disadvantages are listed in Table 3.

\subsection{Physical}

Physical pretreatment methods include thermal treatment, freezing and thawing, microwave radiation, ultrasonication, radiation, and milling.

\subsubsection{Thermal}

Thermal pretreatment facilitates HPB growth, ultimately suppressing methanogenic activity. The formation of spores shows the presence of HPB while non-spore-forming bacteria (methanogens and non-sporulating HPB) are killed during this pretreatment method [29]. Heat-shock is used to assess hydrogen generation by the mixed and anaerobic communities. Compared to untreated culture, thermally shocked or acid-treated culture shows no methanogenic activity [39]. The ability of anaerobic seed sludge to produce hydrogen has been studied using soluble starch. Different heat pretreatment techniques have been reported that result in efficient hydrogen production [40]. The $\mathrm{pH}$ is also a critical factor in methanogenic activity during fermentative biohydrogen production [29]. Two essential parameters that should be optimized for effective pretreatment are the pretreatment time and temperature. Most hydrogen consumers are effectively inhibited by short pretreatment time and temperature, as high values of these factors lead to a decrease in hydrogen production [41]. Heat-shock pretreatment of the inoculum for dark 
fermentation hydrogen production uses various temperature and pretreatment times and gives impressive results [29].

\subsubsection{Freezing and Thawing}

Physical pretreatment is a novel approach involving freezing and thawing. When microalgal biomass is freeze-dried in a lyophilizer, large ice crystals disrupt the cell and release intracellular components at room temperature [43]. Various freezing and thawing procedures are used. These include: high-pressure freezing, dehydro-freezing, the application of anti-freeze protein, ice nucleation (in freezing), high-pressure microwave thawing, and ohmic thawing (in thawing). Freezing applies two processes: change in phase from liquid to solid and lowering the temperature. When water freezes at atmospheric pressure, the increased volume leads to the formation of ice that has a lower density than liquid water [44]. The freezing procedure is primarily utilized for large-scale food preservation where crystal formation is necessary, and a significant heat gradient exists $[45,46]$.

Thawing is usually slower than freezing. In the food industry, thawing is a new application. According to some studies, it can preserve food quality and reduce necessary thawing time $[47,48]$. Thawing has various effects that have been investigated for a long time, including protein denaturation, gelatinization of starch, and inactivation of enzymes. It can be used to sterilize microorganisms and preserve food without heating [47]. Thawing helps in releasing soluble intracellular components from the substrate at $25^{\circ} \mathrm{C}$ in $12 \mathrm{~h}$ [49].

\subsubsection{Microwave Radiation}

Microwave radiation is generally used as a pretreatment method for feedstock with lignocellulosic components. This pretreatment method may be preferred due to factors such as the ease with which it degrades the cellulose fraction structure, ease of operation, minimal inhibitor formation, high heating capacity in a short time, and low energy consumption (Table 3). Switchgrass hydrolyzed with cellulase enzyme, soaked in water, and microwave irradiated had a total sugar production of $34.5 \mathrm{~g} / 100 \mathrm{~g}$ biomass [50,51]. Microwave irradiation is an economical and cost-effective way of removing microorganisms and does not cause any harm to the environment. A previous study suggested that microwave heating (at $850 \mathrm{~W}$ for $3 \mathrm{~min}$ ) increased soluble chemical oxygen demand COD in sludge [52].

\subsubsection{Ultrasonication}

Ultrasound irradiation reduces treatment time and chemical or enzyme requirements. Overall, this approach is regarded as a unique and eco-friendly technique that provides a high degree of intensification [53]. It works on the activated sludge's physical, chemical, and biological properties (Table 3). Ultrasound irradiation is the most favorable inoculum pretreatment method for the utilization of activated sludge as an inoculum in hydrogen production by dark fermentation. The effectiveness of ultrasonic irradiation pretreatment for improving hydrogen production before anaerobic fermentation from complex food waste has been investigated [54,55]. Hydrogen production was improved by an increase in total solids (TS) concentration and ultrasound time. The significant enhancement of hydrogen yield - up to $75 \%$ and a rate of $104 \%$-implies that ultrasound irradiation could be used for enhanced biohydrogen production from food waste [54,55].

\subsubsection{Radiation}

The radioisotope Cobalt- 60 emits gamma radiation, which has been used in substrate treatment for biohydrogen production. Gamma radiation easily penetrates lignocellulose, damaging lignin and cellulose structure through the formation of free radicals, which cause deterioration of the biomass. This approach was assessed and compared for long-term viability in enriching hydrogen-producing bacteria in dark fermentation with glucose as a substrate in batch experiments [56]. The results showed that among different pretreatment methods, seed sludge pretreated with ionizing radiation produced the maximum hydrogen 
rate and yield, and a substrate degradation rate of $525.6 \mathrm{~mL}, 37.2 \mathrm{~mL} / \mathrm{h}, 267.7 \mathrm{~mL} / \mathrm{g}$ glucose (2.15 mol/mL glucose), and $98.9 \%$, respectively [56]. The fermentation process was studied under ideal conditions using gamma-irradiated sludge as inoculum. Another approach that could be used as inoculum pretreatment for dark fermentation is infrared radiation. For the first time, the efficient conversion of wheat-straw waste into biohydrogen gas was reported using cow-dung compost [57]. The maximum cumulative hydrogen yield of $68.1 \mathrm{~mL} \mathrm{H}_{2} / \mathrm{g}$ total volatile solids was found after $12.65 \mathrm{~h}$ of fermentation utilizing raw wheat straw and $\mathrm{HCl}$.

Table 3. Pretreatment methods and their advantages and disadvantages [10,42].

\section{Mechanical Methods}

\begin{tabular}{|c|c|c|c|}
\hline Pretreatment & Cell Disruption Method & Advantages & Disadvantages \\
\hline Bead milling & $\begin{array}{l}\text { Cell wall grinding with } \\
\text { spinning solid beads. }\end{array}$ & $\begin{array}{l}\text { Applicable for wet microalgal } \\
\text { pastes and components that } \\
\text { can be easily separated. } \\
\text { Reduced cellulose } \\
\text { crystallinity. }\end{array}$ & $\begin{array}{l}\text { High energy required. } \\
\text { Heat generated may cause } \\
\text { thermal degeneration. } \\
\text { High installation cost. } \\
\text { Beads should be } \\
\text { replaced periodically. }\end{array}$ \\
\hline Ultrasonication & $\begin{array}{l}\text { Cavitation effect and acoustic } \\
\text { streaming from ultrasonic } \\
\text { waves create high pressure } \\
\text { and heat for disrupting cell }\end{array}$ & $\begin{array}{l}\text { High disruption efficiency. } \\
\text { Brief pretreatment time. } \\
\text { Components such as } \\
\text { solvent/beads are } \\
\text { not required. }\end{array}$ & $\begin{array}{l}\text { High energy required. } \\
\text { Cooling required for the } \\
\text { excess heat generated. } \\
\text { Oxidative free radicals formed } \\
\text { cause damage. }\end{array}$ \\
\hline Microwaves & $\begin{array}{l}\text { Interaction between } \\
\text { high-frequency shock waves } \\
\text { and charged molecules creates } \\
\text { high-pressure and heat to } \\
\text { disrupt cells. }\end{array}$ & $\begin{array}{l}\text { High disruption efficiency. } \\
\text { Short pretreatment time. } \\
\text { Low energy demand. } \\
\text { Easy to scale up. }\end{array}$ & $\begin{array}{l}\text { Component structure may } \\
\text { change due to changes in } \\
\text { non-covalent interactions. } \\
\text { High maintenance cost. } \\
\text { Cooling required for excess } \\
\text { heat generated. }\end{array}$ \\
\hline
\end{tabular}

Thermal Methods

Biomass is exposed to steam at high $\mathrm{T}$ and $\mathrm{P}$ followed by depressurization that causes an explosion to rupture the cell membrane.

Biomass freezing to form large ice crystals that expand and

Freezing and thawing disrupt the cell wall. Excess disruption with repeated freeze-thaw cycles.
High cell disruption efficiency. Low maintenance.

Resistant to corrosion.

Mild operating conditions, suitable for extracting sensitive components. Biomass blending is not needed.
High temperature

(180-240 $\left.{ }^{\circ} \mathrm{C}\right)$ and pressure (1.03-3.45 MPa).

Disruption efficiency varies with species.

Time-consuming. Energy and cost-intensive.

\section{Chemical methods}

Acid- hydrolysis of cell wall polymers.

Acid/alkali treatment Alkali- saponification of cell wall lipids for cell disruption.
Low energy demand

Low temperature.

Short reaction time.

Easy to scale up.
Highly prone to corrosion.

Formation of fermentation inhibitors (furfurals). Protein denaturation

\section{Biological methods}

Enzymatic hydrolysis/ Fungal Treatment
Hydrolysis of the cell wall by enzymes from bacteria and fungi destroys cell wall polymers to access intracellular glucans.
Mild reaction conditions.

High product quality and purity.

Low energy demand.

No chemicals required.
Enzyme is costly.

Enzyme specificity requires a cocktail of enzymes.

Long reaction time (2-4 weeks).

\subsubsection{Milling}

Milling is the initial step of the pretreatment process and is done to increase the surface area of the substrate molecules. Milling techniques utilized in biofuel production include 
two-roll milling, bead milling, hammer milling, disc milling, and colloid milling [58]. After chipping, milling, and grinding, the final particle size of the feedstock may be reduced to a few $\mathrm{mm}(0.2-10 \mathrm{~mm}$ ) (Table 3). A disadvantage of dry milling is the consumption of a high amount of energy that could bead dressed by wet milling [59]. Because of its low energy usage, wet disc milling has also become a common pretreatment method. Compared to hammer milling, which creates finer bundles, disc milling improves cellulose hydrolysis by producing more fibers $[60,61]$. Compared to ball milling, attrition and planetary mills are more effective at reducing biomass size. Other milling methods produce the lowest quantity of glucose and galactose, whereas planetary milling produces the most. It should be emphasized that none of the mill pretreatment procedures yield hazardous chemicals such as hydroxyl methyl furfuraldehyde (HMF) or linolenic acid (LA).

Milling is used before enzymatic hydrolysis and other pretreatment procedures such as chemical or physicochemical approaches. Methods of pretreatment, such as chemical or mechanical milling, are classified as either dry or wet, and the type of biomass used determines which method should be employed. Dry biomass such as napier grass and maize stover is often processed using extruders, roller mills, cryogenic mills, and hammer mills. Colloid milling, fibrillation, and dissolving are also appropriate for pretreatment of wet biomass such as energy cane, wheat bran, or wheat straw [62].

\subsection{Chemical Pretreatment Technologies}

Various chemical pretreatment technologies have been reported to improve biohydrogen production for either inoculum or substrate. Chemical pretreatment agents include acids, alkalis, methanogen inhibitors such as 2-bromoethane sulfonate (BES) or 2-bromoethane sulfonic acid (BESA) ozonolysis, chloroform, iodopropane, and acetylene.

\subsubsection{Acid and Alkali Pretreatment}

Acid and alkali pretreatments are the most widely used methods for enriching or suppressing $\mathrm{HCB}$, considering the susceptibility of non-sporulating hydrogen consumers to $\mathrm{pH}$ changes [63]. The most commonly used acids are $\mathrm{HCl}, \mathrm{H}_{2} \mathrm{SO}_{4}$, and $\mathrm{HNO}_{3}$, having a concentration ranging from 0.1 to $6.0 \mathrm{M}[30,64-66]$ and $\mathrm{pH}$ stretching from 2.0 to $4.0[39,64,67]$. In the case of alkali pretreatment, $\mathrm{NaOH}, \mathrm{KOH}$, and $\mathrm{Ca}(\mathrm{OH})_{2}$ are widely used, with concentrations ranging from 1.0 to $8.0 \mathrm{M}$ and $\mathrm{pH}$-value from 10 to 12 [43,65,66,68]. Acid and alkali pretreatments are most commonly used in selective hydrogen-producing cultures for dark fermentation [43]. Acid pretreatment may improve the solubilization of hemicellulose but is ineffective in delignification $[69,70]$. Alkaline solutions saponify the ester bonds in lignocellulosic substrates, disintegrating their crystalline structure and subsequently enhancing hydrolysis. Dilute alkali pretreatment is suitable for the subsequent hydrolysis by enzymes and enhances residual polysaccharide reactions. Pretreatment with $\mathrm{Ca}(\mathrm{OH})_{2}$ increased the crystallinity index by removing amorphous substances [71]. Another study revealed that $\mathrm{Ca}(\mathrm{OH})_{2}$ can remove the group of acetyls from hemicellulose to increase the digestibility of cellulose and reduce enzyme steric obstruction [72]. Pretreatment using $\mathrm{CaO}_{2} / \mathrm{CaO}$ enhanced both biohydrogen production and biodegradation of wheat straw. At $6 \% \mathrm{CaO}$ and $121{ }^{\circ} \mathrm{C}$, a maximum $\mathrm{H}_{2}$ yield of $114 \mathrm{~mL}$ per $\mathrm{g}$ of total solids (TS) was attained. Moreover, $\mathrm{CaO}_{2}$ pretreatment under identical conditions gave a maximum $\mathrm{H}_{2}$ yield of $(71.8 \mathrm{~mL} / \mathrm{g} \mathrm{TS})$, higher than that of the control group $(43.2 \mathrm{~mL} / \mathrm{g}$ TS) treated with hot water at $12{ }^{\circ} \mathrm{C}$ [72]. Considering the pretreatment costs and the capability of $\mathrm{H}_{2}$ production, $\mathrm{CaO}$ proved to be a better pretreatment agent than $\mathrm{CaO}_{2}$ [73]. Among acids, $\mathrm{HCl}$ and $\mathrm{H}_{2} \mathrm{SO}_{4}$ are the most widely employed, while $\mathrm{NaOH}$ is a commonly used alkali for pretreatment [74]. Pretreating complex substrates using acids is an economical and efficient method, but it has the drawback of corroding the reactors. Another drawback of both pretreatments (acid/alkali) is the probability of the formation of inhibitory compounds [63]. Further, adjusting $\mathrm{pH}$ after the pretreatment complicates the process and increases operational costs (Table 3). 


\subsubsection{BES and BESA}

Using chemicals such as 2-bromoethane sulfonate (BES) or 2-bromoethane sulfonic acid (BESA), hydrogen-consuming methanogens can be removed selectively and efficiently. BESA is a coenzyme-M analog found mainly in methanogens and is reported to inhibit the process of acetate production by methanogens [75]. BESA $(25-100 \mathrm{mmol})$ also efficiently destroys methanogenic bacteria present in sludge [76,77]. In mixed microalgal biomass, BESA addition at $\mathrm{pH} 5.5$ results in maximum hydrogen production rate $(210 \mathrm{~mL} / \mathrm{L} /$ day $)$ and yield $(29.5 \mathrm{~mL} / \mathrm{g})$, nearly 3-fold higher than the control [78].

\subsubsection{Ozonolysis}

Ozonolysis is an efficient oxidative pretreatment method to treat lignocellulosic substrates such as wheat straw, bagasse, and green hay. Ozonolysis reduces lignin in the lignocellulosic biomass, thereby promoting enzymatic hydrolysis to increase the levels of fermentable sugars [79]. Ozonolysis pretreatment is carried out at optimum temperature and pressure. Furthermore, it does not give rise to any noxious inhibitors, making the process sustainable [80]. The main aspect that influences pretreatment with ozone is the biomass moisture content; the higher the moisture content in biomass, the lower the lignin oxidation [63]. Wheat straw ozonolysis produced $4.14 \mathrm{~g} / 100 \mathrm{~g}$ dry matter of oxalic acid and $0.98 \mathrm{~g} / 100 \mathrm{~g}$ dry matter of acetic acid at $40 \%$ moisture, $60 \mathrm{~L} / \mathrm{h}$ air/ozone flow rate, $2.7 \%$ ozone concentration, and $2 \mathrm{~h}$ pretreatment time [81]. Several process parameters such as ozone intake, pretreated biomass composition, sugar yield, and generation of inhibitory compounds capable of inhibiting subsequent phases of enzymatic hydrolysis and hydrolysate fermentation significantly affect process efficiency. Therefore, process parameters must be optimized to attain a viable commercial alternative [82]. Ozonolysis pretreatment was found to be successful due to lignin polymer degradation and minimal effects on lignocellulosic biomass cellulose and hemicellulose content (Figure 4).

\subsubsection{Chloroform}

Chloroform $\left(\mathrm{CHCl}_{3}\right)$ has been used to limit methanogenic activities and therefore enhance biohydrogen yield during dark fermentation [30,43]. Chloroform is used in a similar way to BES or BESA in principle. It inhibits the conversion of methyl-CoM to methane by inhibiting methyl-com reductase (MCR), thereby restricting corrinoid enzymes function. Considering the inhibition of hydrogenotrophic methanogenesis, hydrogen generated during dark fermentation is not consumed, resulting in increased hydrogen yield [83]. Various authors have studied the use of chloroform to suppress HCB in mixed microflora. Chloroform concentration has ranged between $0.0005 \%$ and $5 \%$, with time intervals between $17 \mathrm{~h}$ and $24 \mathrm{~h}$ at ambient temperature [30,43,84-86]. Furthermore, several studies also revealed that the use of chloroform above certain concentrations leads to inhibition of HPB due to adverse effects of chemicals $[30,87,88]$. Luo et al. found that pretreatment with chloroform does not significantly affect hydrogen yield [89].

\subsubsection{Iodopropane}

Iodopropane is an inhibitor used in dark fermentation (DF) to suppress methanogenic activity $[29,68]$. The effects of iodopropane and chloroform on methanogens are more or less similar. As a corrinoid antagonist, iodopropane denatures B12 enzyme activity and functions as a methanogen methyl carrier [90]. As a result, the formation of methyl-CoM is inhibited, suppressing methanogenesis and methane formation [87]. The inhibition of hydrogenotrophic methanogenesis prevents the consumption of produced hydrogen, thus resulting in a higher hydrogen yield [83]. Microflora obtained from sludge pretreated with iodopropane was reported to inhibit methanogenic activity, whereas no impact on hydrogen production was found. Iodopropane has also been able to suppress non-methanogens [29]. 


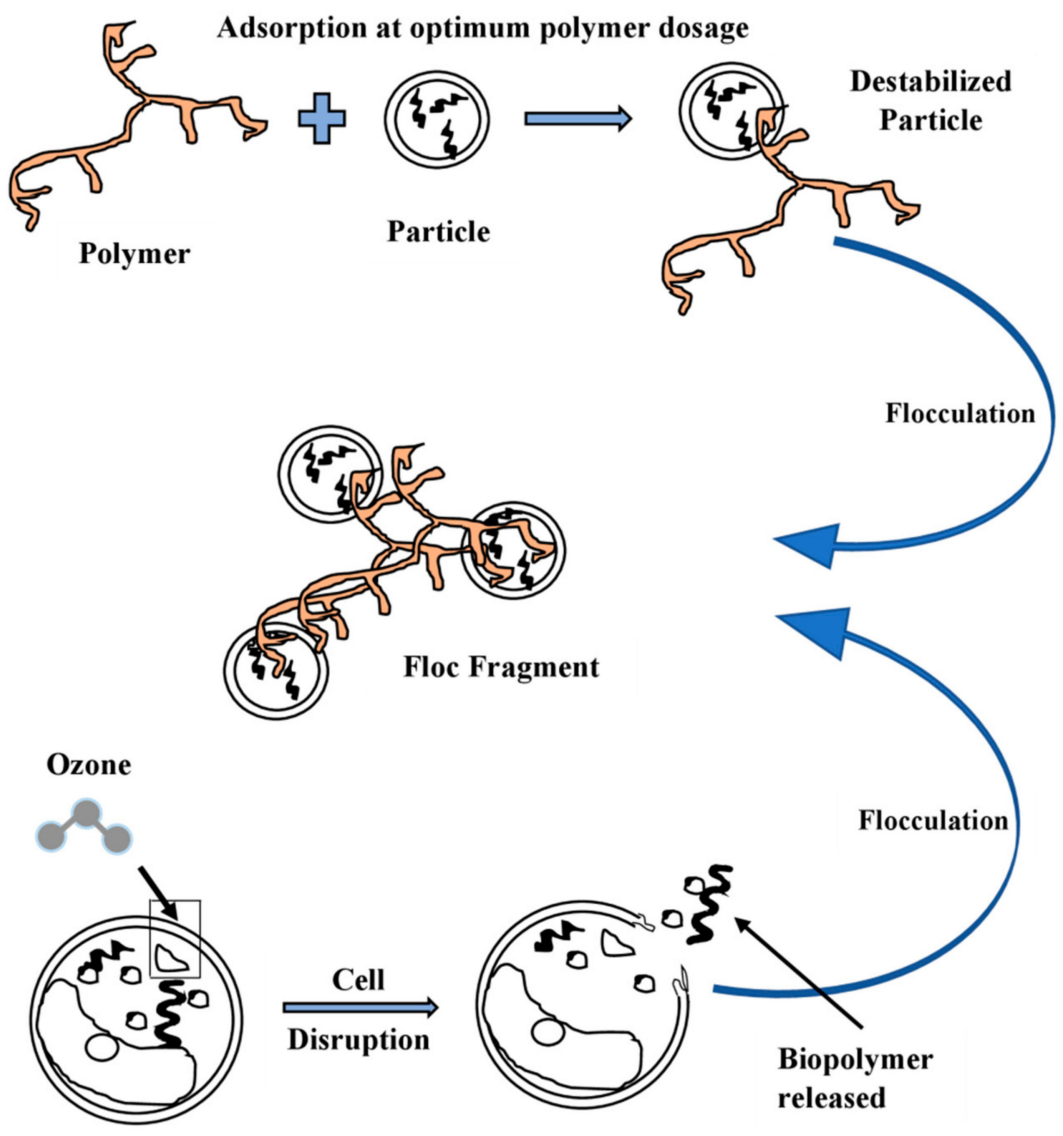

Figure 4. Schematic representation of microalgal cell disruption through ozonolysis.

\subsubsection{Acetylene}

Acetylene is regarded as a non-specific methanogenesis inhibitor. Valdez-Vazquez et al. (2006) reported that inoculum pretreatment with acetylene resulted in higher hydrogen yield [91]. As methanogenic organisms lose their ability to sustain a transmembrane $\mathrm{pH}$ gradient, acetylene exposure reduces methanogenic processes such as methanogenesis and ATP generation [63]. There are several advantages of using acetylene in pretreatment technology for enhanced biohydrogen generation since it is a cheap molecule for inoculum pretreatment and has positive methanogenic inhibitory effects [60]. Methanogenic inhibition was also reported when the inoculum was treated with $1 \%$ acetylene $(v / v)$ using milled paper as a substrate [92].

\subsection{Biological Technologies}

Biological pretreatment technology is more effective and environment-friendly than conventional physical and chemical pretreatment methods due to its lower energy consumption [63]. Plenty of cellulolytic and hemicellulolytic microorganisms exist in nature, and these are targeted for effective biomass pretreatment [93]. Biological pretreatment technology breaks cross-linked structures of lignocellulose residues by increasing the rate of hydrolysis. Numerous biological pretreatment methods can be considered as natural methods of pretreatment, including enzymatic hydrolysis and fungal treatment. Different strains of fungus are used, such as white, brown, and soft-rot fungi that break down hemicellulose, lignin, and also a small amount of cellulose [94]. Lignin degradation with the help of white-rot fungi is mainly attributed to lignin-degrading enzymes, such as peroxidases and laccases [95]. Enzymatic hydrolysis is an alternative for fungal pretreatment, which directly utilizes enzymes to carry out hydrolysis. Poplar leaves containing lignocellulose are considered a substrate to produce biohydrogen [96]. Batch experiments have been 
performed at $35^{\circ} \mathrm{C}$ in the presence of mixed cultures of anaerobic bacteria. Poplar leaves were taken as a substrate, pretreated with acids and alkali, and a mixture of enzymes separately. The cumulative $\mathrm{H}_{2}$ yield from the pretreatment of the substrate using a mixture of enzymes (VicozymeL-2\%) was equal to $44.92 \mathrm{~mL} / \mathrm{g}$ of dry leaves, which is far better (1.34-fold) than the yield obtained by acid/alkali pretreatment. According to [36], with the help of batch production, biohydrogen was obtained from cassava wastewater using seed sludge as a substrate after different pretreatment conditions. Wastewater treated with sonication for $45 \mathrm{~min}$ at $\mathrm{pH} 7$ yields $0.913 \mathrm{~mol} \mathrm{H}_{2} / \mathrm{g}$ of COD. OPTIMASH BG, $0.2 \%$ enzyme pretreatment at $\mathrm{pH} 7$ yields $4.24 \mathrm{~mol} \mathrm{H}_{2} / \mathrm{g}$ of COD. Alpha-amylase $(0.2 \%)$ pretreatment at pH 7 yields 5.02 mol H$_{2}$ g COD. The major drawback of biological treatment technology that limits its use industrially is the sluggish hydrolysis rate of lignocellulose [82].

\subsubsection{Hybrid Technologies}

Numerous experiments have been conducted to enhance the yield of hydrogen using a combination of two or more pretreatment techniques. The methods mentioned above are combined for substrate pretreatment, such as physical and chemical methods [97].

\subsubsection{Combined Technologies for Substrates and Inoculum}

Combined technologies widely used for the pretreatment of substrates involve heat with acid and alkali $[33,98,99]$. Pretreatment of activated sludge with 0.5 percent $w / v \mathrm{HCl}$ acid followed by $15-60$ min of heating at $110^{\circ} \mathrm{C}$ showed the maximum hydrogen yield (155.6\% in $45 \mathrm{~min}$ ) compared to control [99]. Furthermore, combining alkali, acid, and heat pretreatment with sonication gave $180.4 \%$ hydrogen yield compared to untreated food waste. In addition, the combination of ozone and sonication for pretreating activated sludge led to an increase of $\mathrm{H}_{2}$ by $686.4 \%$ compared to the untreated sludge $[100,101]$. Despite this, BESA alone released higher hydrogen than the acid and BESA combined [23].

\subsection{Other Advanced Pretreatment Methods}

According to Zabed et al., 2019, several factors need to be considered for a sustainable pretreatment method [102]. These include cellulose content modification for better downstream enzyme hydrolysis, decreasing cellulose and hemicellulose content loss, possible inadequate formation of unwanted inhibitors, reducing energy consumption, and reducing by-product formation and the exhaustion of chemicals. Present pretreatment approaches are incapable of fulfilling the industrial suitability criterion. As a result, developments of various other advanced approaches such as hydrothermal carbonization (HTC), supercritical fluid, ammonia fiber explosion (AFEX), ionic fluids (IFs), low-temperature steep delignification (LTSD), or co-solvent enhanced lignocellulosic fractionation (CELF), have been used for the industrial utilization of biomass.

\subsubsection{Hydrothermal Carbonization (HTC)}

Hydrothermal carbonization (HTC) is an eco-friendly approach for transforming biomass containing high lignocellulose into various value-added products $[103,104]$. Temperature is one of the main variables in hydrothermal carbonization, which significantly influences biomass conversion by structural component degradation. The combined action of hydrothermal reactions disintegrates the chemical bonds of the structural components [105]. This pretreatment is established at a high temperature of subcritical water (less than $374^{\circ} \mathrm{C}$ ). Each component is individually affected by degradation at different temperature ranges. Microalgae biomass is also treated with HTC in the following ways: directly on microalgal biomass, pre-digested microalgal biomass effluents by recycling, and lipid-extracted microalgal cells [106,107]. Natural microalgae are the most widely studied raw material for their HT conversion into products such as fuel, organic chemicals, and hydrochar [107]. HTC is an energy-saving process that is more sustainable at low temperatures (below $300{ }^{\circ} \mathrm{C}$ ). For heating at high temperatures, processes such as pyrolysis or microwave heating are preferred [108]. Hydrothermal carbonization was found suitable 
for converting water hyacinth to hydrochar [109]. Hydrochar, HTC's solid, hydrophobic and nontoxic product, is employed as adsorbent/activated carbon in treating wastewater [110-112]. Direct conversion of biomass into a carbon product and the formation of gas and liquid phases is an example of recent advancements in HTC. Furthermore, many functional groups that involve oxygen are retained over the hydrochar surface $[113,114]$. The content of cellulose, hemicellulose, and lignin affects the amount and yield of hydrochar [112]. An autoclave reactor at high pressure in the range of 0.6 to $1.5 \mathrm{bar}$, with temperature varying from 160 to $240{ }^{\circ} \mathrm{C}$, was used for performing the HTC experiment. The residence time in the experimental process was in the range of 30-120 $\mathrm{min}$ [113].

\subsubsection{Supercritical Fluid}

When lignocellulosic material is pretreated in a supercritical manner that involves high temperature and pressure conditions, we obtain biomass with an increased surface area at enhanced mass transfer rates along with lignin getting separated from the raw materials (e.g., wood chips, rice straw, switchgrass, etc.) [114,115]. SC- $\mathrm{CO}_{2}$ is most widely used for extracting lignin and lipids as it is relatively nontoxic, readily available, cheap, and has lower critical values of temperature and pressure [116]. The diffusion of $\mathrm{CO}_{2}$ into biomass results in the formation of carbonic acid that hydrolyzes hemicellulose. In the next step, the sudden release of pressure disrupts biomass structure resulting in increased availability of cellulose [117]. SC- $\mathrm{CO}_{2}$ is operable at low temperatures and high pressure compared to thermal treatments that reduce inhibitors formed by lignin and hemicellulose degradation. Owing to its high diffusivity and low viscosity, $\mathrm{SC}-\mathrm{CO}_{2}$ is more efficient for wet biomass, and it can also be combined with other pretreatments for further improvement in cellulose digestibility. In the case of sugarcane bagasse pretreated with $\mathrm{SC}-\mathrm{CO}_{2}$, the glucose yield of enzymatic hydrolysis could be up to $72 \%$, whereas $20 \%$ higher glucose yield could be achieved by combining $\mathrm{SC}-\mathrm{CO}_{2}$ with alkali pretreatment as compared to alkali pretreatment alone [118].

\subsubsection{Ammonia Fiber Explosion and Ammonia Pretreatment}

Ammonia fiber explosion (AFEX) involves physical effects such as high temperature and pressure, and chemical effects such as $\mathrm{NH}_{3}$, to reduce the biomass's unresponsiveness towards hydrolytic enzymes. In the AFEX method, the biomass is reacted with liquid anhydrous $\mathrm{NH}_{3}$ for 5 to $60 \mathrm{~min}$ in a temperature ranging from 60 to $100{ }^{\circ} \mathrm{C}$ and in pressure ranging from 1.7 to $2.1 \mathrm{MPa}$ with water-load variations [119]. AFEX generally operates on dry biomass $(w / w)$ with a dosage ratio of $(1: 1 / 2: 1)$; this aqueous biomass is then given heat treatment in a temperature range from 60 to $120^{\circ} \mathrm{C}$ and pressure of $3 \mathrm{MPa}$ for a duration of $30 \mathrm{~min}$ [102]. At present, AFEX has less application in microalgae biomass hydrolysis, but recent research has shown that free ammonia in pretreating algal biomass remarkably enhances the production of $\mathrm{CH}_{4}$ and $\mathrm{H}_{2}$ under anaerobic conditions [120,121]. In the latest study, co-digestion of sugarcane bagasse (SCB) and cow manure by AFEX enhanced the $\mathrm{N}_{2}$ content of the biomass and enhanced the biodegradation capability SCB. As a result, the methane yield increased to $292-299 \mathrm{~L} / \mathrm{kg}$ of volatile solids, and the methane content of biogas increased to $57-59 \%$, v/v [122]. Since AFEX-treated biomass is a dry-to-dry process, it produces negligible significant inhibitors during pretreatment. Thus, water-washing or further detoxification is not required for biomass treated with AFEX, as it can be easily hydrolyzed and fermented [123].

\subsubsection{Ionic Liquid-Based Pretreatment}

Ionic Liquids (ILs) are solvents with high thermal stability and they are environmentally safe, relatively nontoxic, and less volatile. ILs notably remove hemicellulose and lignin from lignocellulosic biomass while releasing cellulose [124-126]. Acidic ILs have been used to solubilize lignocellulosic biomass partially or entirely. After the dissolution of wood (either partially or completely), the dissolved fractions can be distinguished from the undissolved ones using four techniques. When there is no requirement for biomass fraction- 
ation, the first strategy is usually applied. After the biomass' partial/complete dissolution, an anti-solvent is employed in the regeneration of the reaction mixture entirely without fractionation. The second technique involves the complete dissolution of lignocellulosic biomass and selective fractionation into polysaccharides and lignin. The third technique is used to separate dissolved and undissolved biomass by filtration/centrifugation before regeneration. The fourth technique fractionates lignin, a polysaccharide-rich part, and undissolved biomass into three parts [127]. The lignin and hemicellulose can be dissolved partially with ILs. ILs based on imidazolium pretreatment eliminated lignin in the range of $15-92 \%$ from softwood biomass (e.g., pine, switchgrass, willow, etc.) and agricultural residue [128]. Pretreatment of biomass with ionic liquids and hydrolysis with enzymes gave $90 \%$ glucose and $25 \%$ hemicellulose. Acid/alkali pretreatment methods produce less reducing sugar than ILs for rice and barley straw. To reduce the cost of the consolidated process, IL-tolerant enzymes have been created to saccharify lignocellulosic biomass. For using biomass pretreatment industrially, factors such as recovery, cost, reusing ionic liquids, etc., become significant [129].

\subsubsection{Low-Temperature Steep Delignification (LTSD)}

In low-temperature steep delignification (LTSD), oxygen, nontoxic chemicals, and bases are used in small concentrations for lignocellulosic biomass conversion. This process uses the lowest possible concentrations of chemicals that are nontoxic under mild operating conditions, resulting in high yield and a high rate of conversion. The chemicals and enzymes used may also be recovered. Mild operating conditions segregate the biomass into lignin, hemicellulose, and cellulose. In this process, lignocellulosic biomass is separated into three fractions: lignin, cellulose, and hemicellulose, with lignin being extracted 90\% from the biomass. The steps involved in the process include enzymatic hydrolysis, fermentation, and distillation. In one study, this method was used on hardwood chip conversion, where glucan was obtained with a yield of $78 \%$ after the enzymatic hydrolysis. The chemicals used were sodium chlorite, $\mathrm{H}_{2} \mathrm{O}_{2}$, and $\mathrm{O}_{2}$ [130].

\subsubsection{Co-Solvent Enhanced Lignocellulosic Fractionation (CELF)}

In this pretreatment method, acetylated lignin is dissolved from lignocellulosic biomass with enhanced hydrolysis of cellulose in water by combining organic solvents, water $\left(\mathrm{H}_{2} \mathrm{O}\right)$, dilute sulphuric acid $\left(\mathrm{H}_{2} \mathrm{SO}_{4}\right)$, and tetrahydrofuran to achieve a high yield of reducing sugar with minimal use of enzyme [131]. Additionally, CELF uses co-solvents such as 1,4-dioxane, acetone, and organic solvents such as methanol and ethanol for effective lignin fractionation from biomass. The process operates at high temperatures $\left(160-180{ }^{\circ} \mathrm{C}\right)$ and generates several by-products converted to other valuable products [132].

\section{New Approaches to Biomass-Based Biohydrogen Production}

Three processes have been studied based on the pretreatment method, hydrolysis, and fermentation process being carried out in the same/separate reactor.

\subsection{Separate Hydrolysis and Fermentation (SHF)}

Separate Hydrolysis and Fermentation (SHF) is an effective approach that involves sequential enzymatic hydrolysis and fermentation (Figure 5). However, to obtain a better biohydrogen yield, the conditions for hydrolysis should be optimal [133]. The sugars hexose and pentose are found in lignocellulosic biomass hydrolysate; to further enhance $\mathrm{H}_{2}$ yield, microbes are essential to ferment both sugars. The bacterium Thermoanaerobacterium thermosaccharolyticum W16 uses fermentable sugars obtained from hydrolysis to produce biohydrogen. Biomass pretreatment procedures produce inhibitors, which should be removed during the detoxification step. Biological pretreatment and saccharification methods have been reported to avoid the production of inhibitors. In the case of enzymatic saccharification, Trichoderma viride crude cellulase was utilized to produce reducing sugar [134]. When steam-exploded switchgrass was used for $\mathrm{H}_{2}$ production, the yield 
obtained by using the hydrolysate was $99.8 \mathrm{~mL} / \mathrm{g}$ of substrate [135]. Pretreatment methods involving acid and alkali have a significant influence on grass saccharification for producing $\mathrm{H}_{2}$. In the case of grass with acid pretreatment, the $\mathrm{H}_{2}$ produced was $72.2 \mathrm{~mL} / \mathrm{g}$ of the substrate.

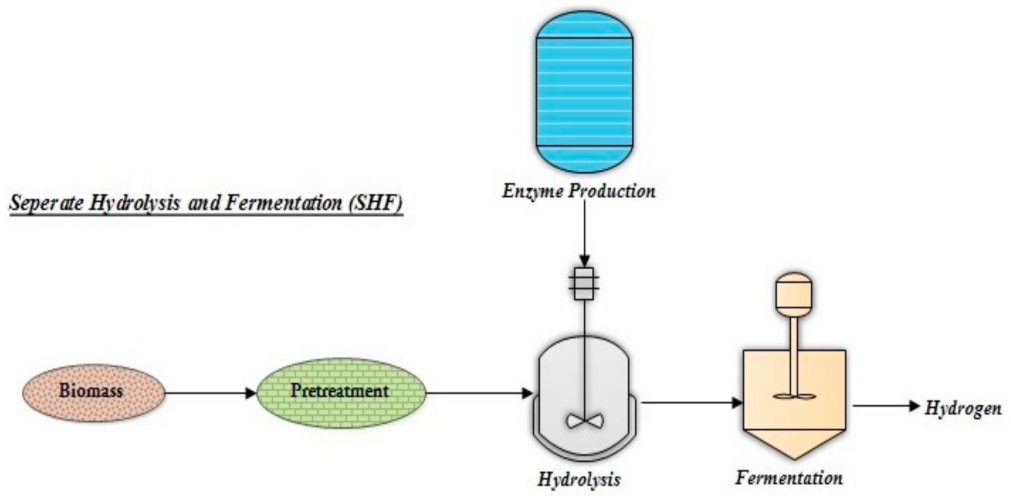

Figure 5. Schematic representation of separate hydrolysis and fermentation (SHF) for biohydrogen production.

\subsection{Simultaneous Saccharification and Fermentation (SSF)}

Simultaneous Saccharification and Fermentation (SSF) is carried out in the same reactor by utilizing different enzymes for saccharification and $\mathrm{H}_{2}$ fermentation (Figure 6). SSF can improve process time and cost while also removing product inhibition during cellulose hydrolysis [136]. Using SSF, Clostridium butyric ASI 209 was selected to produce $\mathrm{H}_{2}$ from steam-exploded corn, and the effect of variables such as $\mathrm{pH}$ or enzyme-loading on the productivity of $\mathrm{H}_{2}$ was noted. Some other studies noted how acetic acid and enzymeloading affected $\mathrm{H}_{2}$ production. When the acetic-acid steam-exploded procedure was used to increase the production of $\mathrm{H}_{2}$, Ethanoligenes harbinese $\mathrm{B} 49$ resulted in high $\mathrm{H}_{2}$ yield and production [133]. SSF produced biohydrogen from fermentable sugars derived from fungal-pretreated cornstalk using enzymes from T. viride and T. thermosaccharolyticum W16. After studying various process parameters, a maximum yield of $89.3 \mathrm{~mL} \mathrm{H}_{2}$ /gm substrate was reported [134].

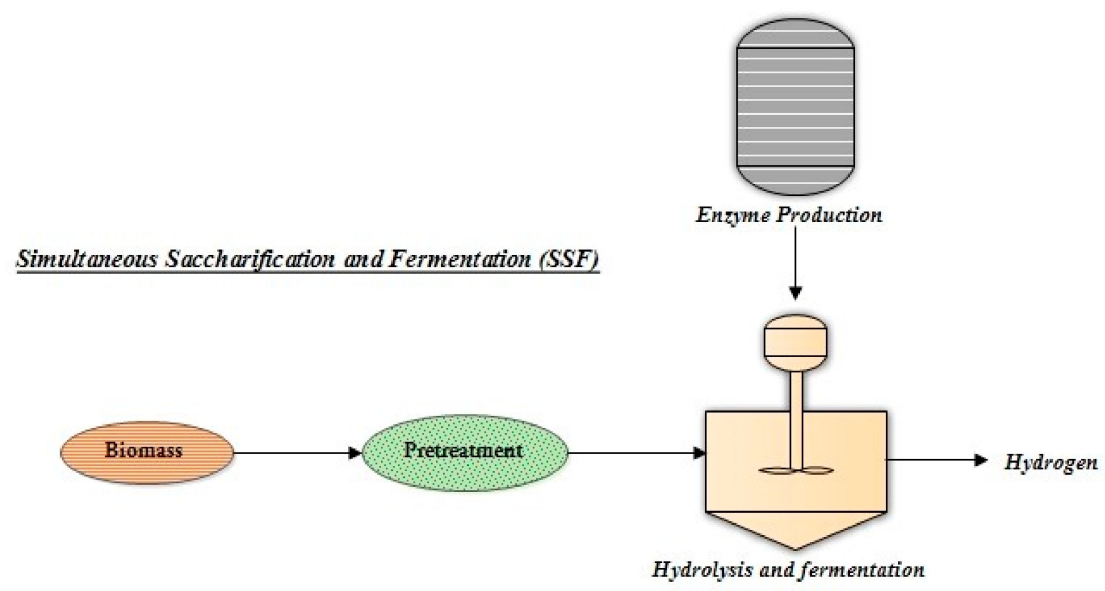

Figure 6. Schematic process of simultaneous saccharification and fermentation (SSF) for biohydrogen production.

\subsection{Consolidated Bioprocessing (CBP)}

CBP is an integrated and economically feasible single-step process (Figure 7). Compared with fermentation, the $\mathrm{pH}$ and temperature required here for enzymatic hydrolysis are different. Compared to SHF and SSF technologies, the CBP operating technique is more 
straightforward. No enzyme is added, the chances of contamination are less, the energy requirement is low, and minimal investment is required. CBP encompasses a mixed-culture activity producing a synergistic effect, thus giving a high $\mathrm{H}_{2}$ yield. Reduced time for fermentation, high substrate conversion, and eliminated inhibitory compounds are some of the benefits of using mixed culture in this process [137].

\section{Consolidated bioprocessing (CBP)}

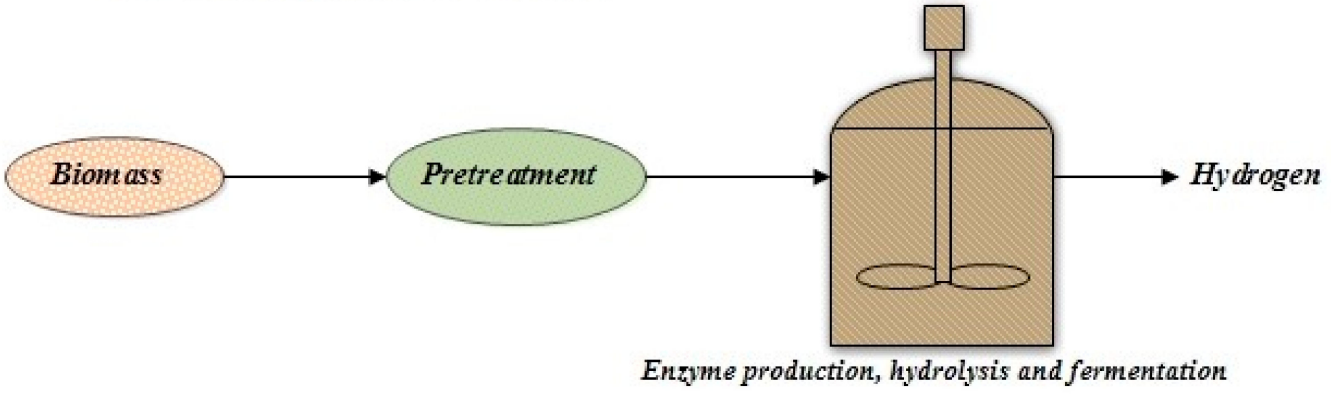

Figure 7. Process outlook of consolidated bioprocessing (CBP) for hydrogen production.

\subsection{Integrated Strategy for Alternative Bioenergy Resources in Addition to $\mathrm{H}_{2}$}

Along with hydrogen, several byproducts such as lactic acid, ethanol, and lactic acid are also produced during fermentation. Recovery of these products is desirable to make the process more feasible and economical.

\subsubsection{Co-Production of Bio Alcohols and VFAs}

Complex lignocellulosic biomass is prefered to be utilized as a substrate to minimize the impact on the environment. In aerobic bacteria, extracellular enzymes break down cellulose, while in anaerobic bacteria, hydrolysis of cellulose is mediated by the cellulosome, a multi-enzyme extracellular complex. Alcohols, VFAs, and $\mathrm{H}_{2}$, can be produced simultaneously using mixed culture [138]. Cellulolytic E. coli have been utilized on bovine rumen to produce $0.36 \mathrm{~g} / \mathrm{L}$ of ethanol and an $\mathrm{H}_{2}$ yield of $4.41 \mathrm{~mL} / \mathrm{gm}$ from corn straw. Sweet sorghum stalk, plant-based biomass, contains structural carbohydrates, e.g., cellulose, hemicellulose, and nonstructural sugars, e.g., fructose, glucose, sucrose, that affect the yield of $\mathrm{H}_{2}$. A two-step dark fermentation method has been used with Clostridium thermosaccharolyticum to utilize carbohydrates (structural and nonstructural) of sweet sorghum stalk to produce VFAs and hydrogen. In the first step, nonstructural sugars were used by $C$. thermosaccharolyticum to give $3.27 \mathrm{mmol} \mathrm{H}_{2} / \mathrm{g}$ substrate, $1.18 \mathrm{~g} / \mathrm{L}$ of acetic acid, and $0.97 \mathrm{~g} / \mathrm{L}$ of butyric acid. The remaining biomass, when treated with dilute $\mathrm{H}_{2} \mathrm{SO}_{4}$ before being refermented with $C$. thermosaccharolyticum, produced $2.5 \mathrm{mmol} \mathrm{H} / \mathrm{gm}$ of the substrate, $0.99 \mathrm{~g} / \mathrm{L}$ acetic acid, and $1.09 \mathrm{~g} / \mathrm{L}$ butyric acid [139].

\subsubsection{Co-Production of Methane and Hydrogen}

The energy density of hydrogen is high $(142 \mathrm{~kJ} / \mathrm{g})$, followed by methane having $55.5 \mathrm{~kJ} / \mathrm{g}$ [140]. Acidogenic microorganisms utilize lignocellulosic biomass to produce $\mathrm{CO}_{2}$, $\mathrm{H}_{2}$, and VFAs after hydrolyzing them into free sugars. Hydrogenotrophic methanogens use $\mathrm{CO}_{2}$ and $\mathrm{H}_{2}$ dissolved in the medium to generate $\mathrm{CH}_{4}$, whereas acetogenic bacteria do conversion of acetic acid into methane and $\mathrm{CO}_{2} \cdot \mathrm{H}_{2}$ is scavenged by hydrogenotrophic methanogens, which reduces $\mathrm{H}_{2}$ production. Dark fermentation is preferred over anaerobic fermentation to prevent the formation of methane and methanogens, resulting in increased $\mathrm{H}_{2}$ and $\mathrm{CO}_{2}$ production. Lignin amount was decreased on pretreatment with alkaline $\mathrm{H}_{2} \mathrm{O}_{2}$, accompanied by an increase in substrate conversion efficiency to around 86 percent, resulting in $\mathrm{H}_{2}$ yields of $303 \mathrm{~mL} / \mathrm{g}$ COD. In recirculated-two-phase anaerobic digestion (RTPAD), both dark fermentation and methane-producing processes are combined. Hydrogen is produced in the first stage, and the used material of 1st stage that contains byproducts 
is then subjected to methane production in the second stage. After this, the effluent from methanogenesis is recirculated to the dark fermentation unit [141].

\section{Conclusions}

Biohydrogen production is eco-friendly compared to other methods of hydrogen production. It has the potential to replace conventional fossil fuels without releasing greenhouse gases. Hydrogen production from biomass depends upon the type of feedstock utilized. The substrate pretreatment is an important step that affects biohydrogen production. The utilization of substrates such as food, agriculture, and industrial waste after pretreatment could enhance hydrogen yield. So far, no single pretreatment method hydrolyzes biomass efficiently in an eco-friendly way. Many reports suggest that the combination of thermal and enzymatic pretreatments could improve substrate hydrolysis and thus enhance biohydrogen production. However, biological methods may be more eco-friendly and cost-effective compared to other physical and chemical methods. More extensive research is needed to exploit the potential of combined approaches of pretreatment. The pretreatment method employed should be cost-effective, should not be energy-intensive, and should be quicker to hydrolyze substrates. Pretreatment methods such as AFEX and steam explosion require specialized and costly equipment in comparison to simple methods such as milling. The integration of effective and cheap pretreatment methods will improve the hydrolysis of the substrate and thus biohydrogen production, with better hydrogen yields. Most of the studies being carried out on the pretreatment process are at the laboratory scale. Sound technical knowledge and technologies are needed to shift substrate pretreatment processing from the laboratory to commercial scale.

Author Contributions: Conceptualization, H.S., S.T. and P.K.R.; methodology, H.S., S.T., K.A.Q., P.K.R. and M.J.; validation, P.K.R.; data curation, H.S., S.T., P.K.R., K.A.Q. and M.J.; writing-original draft preparation, H.S., S.T., P.K.R. and K.A.Q.; writing-review and editing, H.S., S.T., P.K.R., K.A.Q. and M.J.; supervision, P.K.R.; funding acquisition, K.A.Q. and M.J. All authors have read and agreed to the published version of the manuscript.

Funding: This research was funded by the Deanship of Scientific Research (Deputy for Research and Innovation), Qassim University, Buraydah, Saudi Arabia, under the scheme of fast-track publication number "PHUC-2021-FTF-078" and King Abdullah University of Science and Technology, Thuwal, Saudi Arabia.

Institutional Review Board Statement: Not applicable.

Informed Consent Statement: Not applicable.

Acknowledgments: The authors, H.S., S.T. and P.K.R. are grateful to the Invertis University, Bareilly, Uttar Pradesh, India, for providing the necessary facilities to carry out this study. Additionally, the authors thank Qassim University, Buraydah, Saudi Arabia, and King Abdullah University of Science and Technology, Thuwal, Saudi Arabia, for financially supporting this study.

Conflicts of Interest: The authors declare no conflict of interest.

\section{References}

1. Rai, P.K.; Singh, H.; Mueed, Z.; Kumar, M.; Kumar, A. A Status Report on Biohydrogen Production from Algae. Invertis J. Sci. Technol. 2020, 13, 73-78. [CrossRef]

2. Trchounian, K.; Trchounian, A. Hydrogen production from glycerol by Escherichia coli and other bacteria: An overview and perspectives. Appl. Energy 2015, 156, 174-184. [CrossRef]

3. Rai, P.K. Hydrogen Production from Dairy and Agro Wastes by Integrating Dark-and Photo-Fermentation. Doctoral Dissertation, Banaras Hindu University, Varanasi, India, 2013.

4. Eroglu, E.; Gunduz, U.; Yucel, M.; Turker, L.; Eroglu, I. Photobiological hydrogen production from olive mill wastewater as sole substrate sources. Int. J. Hydrogen Energy 2004, 29, 163-171. [CrossRef]

5. Nguyen, T.A.D.; Kim, K.R.; Nguyen, M.T.; Kim, M.S.; Kim, D.; Sim, S.J. Enhancement of fermentative hydrogen production from green algal biomass of Thermotoganeapolitanaby various pretreatment methods. Int. J. Hydrogen Energy 2010, 35, 13035-13040. [CrossRef] 
6. Seifert, K.; Waligorska, M.; Laniecki, M. Hydrogen generation in photobiological process from dairy waste water. Int. J. Hydrogen Energy 2010, 35, 9624-9629. [CrossRef]

7. Cheng, J.; Xia, A.; Liu, Y.; Lin, R.; Zhou, J.; Cen, K. Combination of dark- and photo-fermentation to improve hydrogen production from Arthrospira platensis wet biomass with ammonium removal by zeolite. Int. J. Hydrogen Energy 2012, 37, 13330-13337. [CrossRef]

8. Ho, K.-L.; Lee, D.-J.; Su, A.; Chang, J.-S. Biohydrogen from lignocellulosic feedstock via one-step process. Int. J. Hydrogen Energy 2012, 37, 15569-15574. [CrossRef]

9. Rai, P.K.; Singh, S.P.; Asthana, R.K. Biohydrogen Production from Cheese Whey Wastewater in a Two-Step Anaerobic Process Appl. Biochem. Biotechnol. 2012, 167, 1540-1549. [CrossRef]

10. Rai, P.K.; Asthana, R.K.; Singh, S.P. Optimization of photo-hydrogen production based on cheese whey spent medium. Int. J. Hydrogen Energy 2014, 39, 7597-7603. [CrossRef]

11. Chaitanya, N.; Sivaramakrishna, D.; Kumar, B.S.; Himabindu, V.; Lakshminarasu, M.; Vishwanadham, M. Selection of pretreatment method for enriching hydrogen-producing bacteria using anaerobic sewage sludge with three different substrates. Biofuels 2016, 7, 163-171. [CrossRef]

12. Rai, P.K.; Kadier, A.; Kumar, M.; Singh, S.P. Utilization of Microalgal Biomass as a Source of Bioenergy. In Role of Photosynthetic Microbes in Agriculture and Industry; Tripathi, K., Kumar, N., Abraham, G., Eds.; Nova Science Publishers: Hauppauge, NY, USA, 2018; ISBN 978-153-614-033-0.

13. Rashidi, B.; Dechesne, A.; Rydahl, M.G.; Jorgensen, B.; Trindade, L.M. Neochlorisoleoabundans cell walls have an altered composition when cultivated under different growing conditions. Algal Res. 2019, 40, 101482. [CrossRef]

14. Liu, Q.; Yao, C.; Sun, Y.; Chen, W.; Tan, H.; Cao, X.; Xue, S.; Yin, H. Production and structural characterization of a new type of polysaccharide from nitrogen-limited Arthrospira platensis cultivated in outdoor industrial-scale open raceway ponds. Biotechnol. Biofuels 2019, 12, 131. [CrossRef] [PubMed]

15. Nagarajan, D.; Chang, J.-S.; Lee, D.-J. Pretreatment of microalgal biomass for efficient biohydrogen production-Recent insights and future perspectives. Bioresour. Technol. 2020, 302, 122871. [CrossRef] [PubMed]

16. Wyman, C.E. Biomass ethanol: Technical progress, opportunities, and commercial challenges. Ann. Rev. Energy Environ. 1999, 24, 189-226. [CrossRef]

17. Agler, M.T.; Wrenn, B.A.; Zinder, S.H.; Angenent, L.T. Waste to bioproduct conversion with undefined mixed cultures: The carboxylate platform. Trends Biotechnol. 2011, 29, 70-78. [CrossRef]

18. Rai, P.K. Recent Advances in substrate utilization for fermentative hydrogen Production. J. Appl. Biol. Biotechnol. 2016, 4, 59-67. [CrossRef]

19. Mohan, S.V.; Babu, V.L.; Sarma, P.N. Anaerobic biohydrogen production from dairy waste water treatment in sequencing batch reactor (AnSBR): Effect of organic loading rate. Enzyme Microb. Technol. 2007, 41, 506-515. [CrossRef]

20. Rai, P.K.; Singh, S.P.; Asthana, R.K. Prospects of utilizing dairy waste for biohydrogen production. Int. J. Biotech. Biosci. 2011, 1, 263-270.

21. Rossi, D.M.; Da Costa, J.B.; De Souza, E.A.; Peralba, M.d.C.R.; Samios, D.; Ayub, M.A.Z. Comparison of different pre-treatment methods for hydrogen production using environmental microbial consortia on residual glycerol from biodiesel. Int. J. Hydrogen Energy 2011, 36, 4814-4819. [CrossRef]

22. Kumar, G.; Bakonyi, P.; Periyasamy, S.; Kim, S.H.; Nemestóthy, N.; Bélafi-Bakó, K. Lignocellulose biohydrogen: Practical challenges and recent progress. Renew. Sustain. Energy Rev. 2015, 44, 728-737. [CrossRef]

23. Venkata Mohan, S. Fermentative hydrogen production with simultaneous wastewater treatment: Influence of pretreatment and system operating conditions. J. Sci. Ind. Res. 2008, 67, 950-961.

24. Yetis, M.; Gunduz, U.; Eroglu, I.; Yucel, M.; Turker, L. Photoproduction of hydrogen from sugar refinery wastewater by Rhodobacter sphaeroides OU 001. Int. J. Hydrogen Energy. 2000, 25, 1035-1041. [CrossRef]

25. Rai, P.K.; Singh, S.P. Integrated dark- and photo-fermentation: Recent advances and provisions for improvement. Int. J. Hydrogen Energy 2016, 41, 19957-19971. [CrossRef]

26. Rai, P.K.; Singh, S.P. Biological production of clean energy: Hydrogen. In Advances in Microbiology; Tiwari, S.P., Rajesh Sharm, R., Rajeeva Gaur, R., Eds.; Nova Science Publishers Inc.: New York, NY, USA, 2013; Volume 2, pp. 55-83, ISBN 978-1-62808-633-1.

27. Wang, Y.Y.; Zhang, Y.L.; Wang, J.B.; Meng, L. Effects of volatile fatty acid concentrations on methane yield and methanogenic bacteria. Biomass Bioenergy 2009, 33, 848-853. [CrossRef]

28. Xie, B.F.; Cheng, J.; Zhou, J.H.; Song, W.L.; Liu, J.Z.; Cen, K.F. Production of hydrogen and methane from potatoes by two-phase anaerobic fermentation. Bioresour. Technol. 2007, 99, 5942-5946. [CrossRef] [PubMed]

29. Zhu, H.; Beland, M. Evaluation of alternative methods of preparing hydrogen producing seeds from digested wastewater sludge. Int. J. Hydrogen Energy 2006, 31, 1980-1988. [CrossRef]

30. Hu, B.; Chen, S. Pretreatment of methanogenic granules for immobilized hydrogen fermentation. Int. J. Hydrogen Energy 2007, 32, 3266-3273. [CrossRef]

31. Luste, S.; Luostarinen, S.; Sillanpää, M. Effect of pre-treatments on hydrolysis and methane production potentials of by-products from meat-processing industry. Hazard. Mater. 2009, 164, 247-255. [CrossRef]

32. Haridoss, S. Studies on biohydrogen production from rice mill waste water using Enterobacter aerogenes MTCC 2822 by Dark Fermentation Process. J. Pet Environ. Biotechnol. 2016, 7, 312. 
33. Ozkan, L.; Erguder, T.H.; Demirer, G.N. Effects of pretreatment methods on solubilization of beet-pulp and bio-hydrogen production yield. Int. J. Hydrogen Energy 2011, 36, 382-389. [CrossRef]

34. Mahmod, S.S.; Jahim, J.M.; Abdul, P.M. Pretreatment conditions of palm oil mill effluent (POME) for thermophilic biohydrogen production by mixed culture. Int. J. Hydrogen Energy 2017, 42, 27512-27522. [CrossRef]

35. Malik, S.N.; Ghosh, P.C.; Vaidya, A.N.; Mudliar, S.N. Ozone pretreatment of biomethanated distillery wastewater in a semi batch reactor: Mapping pretreatment efficiency in terms of COD, color, toxicity and biohydrogen generation. Biofuels 2018, 11, 1-9. [CrossRef]

36. Leano, E.P.; Babel, S. Effects of pretreatment methods on cassava wastewater for biohydrogen production optimization. Renew. Energy 2012, 39, 339-346. [CrossRef]

37. Ramprakash, B.; Muthukumar, K. Comparative study on the performance of various pretreatment and hydrolysis methods for the production of biohydrogen using Enterobacter aerogenes RM 08 from rice mill wastewater. Int. J. Hydrogen Energy 2015, 40, 9106-9112. [CrossRef]

38. Lin, C.-Y.; Lay, C.-H.; Sen, B.; Chu, C.-Y.; Kumar, G.; Chen, C.-C.; Chang, J.-S. Fermentative hydrogen production from wastewaters: A review and prognosis. Int. J. Hydrogen Energy 2012, 37, 15632-15642. [CrossRef]

39. Chaganti, S.R.; Kim, D.-H.; Lalman, J.A. Dark fermentative hydrogen production by mixed anaerobic cultures: Effect of inoculum treatment methods on hydrogen yield. Renew. Energy 2012, 48, 117-121. [CrossRef]

40. Bakonyi, P.; Nemestothy, N.; Simon, V.; Bélafi-Bakó, K. Review on the start-up experiences of continuous fermentative hydrogen producing bioreactors. Renew. Sustain. Energy Rev. 2014, 40, 806-813. [CrossRef]

41. Sivagurunathan, P.; Anburajan, P.; Kumar, G.; Arivalagan, P.; Bakonyi, P.; Kim, S.-H. Improvement of hydrogen fermentation of galactose by combined inoculation strategy. J. Biosci. Bioeng. 2017, 123, 353-357. [CrossRef] [PubMed]

42. Wang, Q.; Gong, Y.; Liu, S.; Wang, D.; Liu, R.; Zhou, X.; Nghiem, L.D.; Zhao, Y. Free Ammonia Pretreatment To Improve Biohydrogen Production from Anaerobic Dark Fermentation of Microalgae. ACS Sustain. Chem. Eng. 2019, 7, 1642-1647. [CrossRef]

43. Dixon, C.; Wilken, L.R. Green microalgae biomolecule separations and recovery. Bioresour. Bioprocess. 2018, 5, 14. [CrossRef]

44. Kalichevsky, M.T.; Knorr, D.; Lillford, P.J. Potential food applications of high-pressure effects on ice-water transitions. Trends Food Sci. Technol. 1995, 6, 253-258. [CrossRef]

45. Martino, M.N.; Otero, L.; Sanz, P.D.; Zaritzky, N.E. Size and location of ice crystals in pork frozen by high-pressure-assisted freezing as compared to classical methods. Meat Sci. 1998, 50, 303-313. [CrossRef]

46. Otero, L.; Martino, M.; Zaritzky, N.; Solas, M.; Sanz, P. Preservation of Microstructure in Peach and Mango during High-pressureshift Freezing. J. Food Sci. 2000, 65, 466-470. [CrossRef]

47. Makita, T. Application of high pressure and thermophysical properties of water to biotechnology. Fluid Phase Equilibria 1992, 76, 87-95. [CrossRef]

48. Zhao, Y.Y.; Fores, R.A.; Olson, D.G. The action of high hydrostatic pressure on the thawing of frozen meat. In Proceedings of the Annual Meeting of Institute of Food Technologist, New Orleans, LA, USA, June 1996; pp. 22-26.

49. Jan, T.-W.; Adav, S.S.; Lee, D.J.; Wu, R.M.; Su, A.; Tay, J.-H. Hydrogen Fermentation and Methane Production from Sludge with Pretreatments. Energy Fuels 2007, 22, 98-102. [CrossRef]

50. Hu, Z.; Wan, Z. Enhancing enzymatic digestibility of switchgrass by microwave-assisted alkali pretreatment. Biochem. Eng. J. 2008, 38, 369-378. [CrossRef]

51. Hong, S.M.; Park, J.K.; Lee, Y. Mechanisms of microwave irradiation involved in the destruction of fecal coliforms from biosolids. Water Res. 2004, 38, 1615-1625. [CrossRef] [PubMed]

52. Thungklin, P.; Reungsang, A.; Sittijunda, S. Hydrogen production from sludge treatment strategy for enhancement of biohydrogen production from complex ultrasonically treated waste-activated sludge. Water Res. 2011, 35, 1038-1046.

53. Chu, C.; Chang, B.-V.; Liao, G.; Jean, D.; Lee, D. Observations on changes in ultrasonically treated waste-activated sludge. Water Res. 2001, 35, 1038-1046. [CrossRef]

54. Gadhe, A.; Sonawane, S.S.; Varma, M.N. Ultrasonic pretreatment for an enhancement of biohydrogen production from complex food waste. Int. J. Hydrogen Energy 2014, 39, 7721-7729. [CrossRef]

55. Gadhe, A.; Sonawane, S.S.; Varma, M.N. Evaluation of ultrasonication as a treatment strategy for enhancement of biohydrogen production from complex distillery wastewater and process optimization. Int. J. Hydrogen Energy 2014, 39, 10041-10050. [CrossRef]

56. Yin, Y.; Hu, J.; Wang, J. Enriching hydrogen-producing bacteria from digested sludge by different pretreatment methods. Int. J. Hydrogen Energy 2014, 39, 13550-13556. [CrossRef]

57. Fan, Y.-T.; Zhang, Y.-H.; Zhang, S.-F.; Hou, H.-W.; Ren, B. Efficient conversion of wheat straw wastes into biohydrogen gas by cow dung compost. Bioresour. Technol. 2006, 97, 500-505. [CrossRef] [PubMed]

58. Kucharska, K.; Rybarczyk, P.; Hołowacz, I.; Łukajtis, R.; Glinka, M.; Kamiński, M. Pretreatment of Lignocellulosic Materials as Substrates for Fermentation Processes. Molecules 2018, 23, 2937. [CrossRef]

59. Chang, V.S.; Burr, B.; Holtzapple, M.T. Lime pretreatment of switchgrass. Appl. Biochem. Biotechnol. 1997, 63-65, 3-19. [CrossRef]

60. Zhao, T.; Zhang, L.; Chen, H.; Zhao, Y. Co-inhibition of methanogens for methane mitigation in biodegradable wastes. J. Environ. Sci. 2009, 21, 827-833. [CrossRef]

61. Kim, H.J.; Chang, J.H.; Jeong, B.Y.; Lee, J.H. Comparison of milling modes as a pretreatment method for cellulosic biofuel production. J. Clean Energy Technol. 2013, 1, 45-48. [CrossRef] 
62. Zeng, M.; Mosier, N.S.; Huang, C.-P.; Sherman, D.M.; Ladisch, M.R. Microscopic examination of changes of plant cell structure in corn stover due to hot water pretreatment and enzymatic hydrolysis. Biotechnol. Bioeng. 2007, 97, 265-278. [CrossRef] [PubMed]

63. Rafieenia, R.; Girotto, F.; Peng, W.; Cossu, R.; Pivato, A.; Raga, R.; Lavagnolo, M.C. Effect of aerobic pre-treatment on hydrogen and methane production in a two-stage anaerobic digestion process using food waste with different compositions. Waste Manag. 2017, 59, 194-199. [CrossRef]

64. $\mathrm{Mu}, \mathrm{Y}$; $\mathrm{Yu}, \mathrm{H}$.-Q.; Wang, G. Evaluation of three methods for enriching $\mathrm{H}_{2}$-producing cultures from anaerobic sludge. Enzyme Microb. Technol. 2007, 40, 947-953. [CrossRef]

65. Mohammadi, P.; Ibrahim, S.; Annuar, M.S.M.; Law, S. Effects of different pretreatment methods on anaerobic mixed microflora for hydrogen production and COD reduction from palm oil mill effluent. J. Clean. Prod. 2011, 19, 1654-1658. [CrossRef]

66. Mohammadi, P.; Ibrahim, S.; Annuar, M.S.M. Comparative study on the effect of various pretreatment methods on the enrichment of hydrogen producing bacteria in anaerobic granulated sludge from brewery wastewater. Korean J. Chem. Eng. 2012, 29, 1347-1351. [CrossRef]

67. Lee, M.-J.; Song, J.-H.; Hwang, S.-J. Effects of acid pre-treatment on bio-hydrogen production and microbial communities during dark fermentation. Bioresour. Technol. 2009, 100, 1491-1493. [CrossRef]

68. Pita, F.; Perez, M. Pretreatment Application of Mixed Sewage Sludge on Self fermentation for Biohydrogen Production; University of Cadiz: Cádiz, Spain, 2011.

69. Hendriks, A.T.W.M.; Zeeman, G. Pretreatments to enhance the digestibility of lignocellulosic biomass. Bioresour. Technol. 2009, 100, 10-18. [CrossRef]

70. Mood, S.H.; Golfeshan, A.H.; Tabatabaei, M.; Jouzani, G.S.; Najafi, G.H.; Gholami, M.; Ardjmand, M. Lignocellulosic biomass to bioethanol, a comprehensive review with a focus on pre-treatment. Renew. Sustain. Energy Rev. 2013, 27, 77-93. [CrossRef]

71. Alvira, P.; Tomás-Pejó, E.; Ballesteros, M.; Negro, M. Pretreatment technologies for an efficient bioethanol production process based on enzymatic hydrolysis: A review. Bioresour. Technol. 2010, 101, 4851-4861. [CrossRef] [PubMed]

72. Mosier, N.; Wyman, C.; Dale, B.; Elander, R.; Lee, Y.Y.; Holtzapple, M.; Ladisch, M. Features of promising technologies for pre-treatment of lignocellulosic biomass. Bioresour. Technol. 2005, 96, 673-686. [CrossRef] [PubMed]

73. Zhang, J.; Kong, C.; Yang, M.; Zang, L. Comparison of Calcium Oxide and Calcium Peroxide Pre-treatments of Wheat Straw for Improving Biohydrogen Production. ACS Omega 2020, 5, 9151-9161. [CrossRef] [PubMed]

74. Rorke, D.; Gueguim Kana, E.B. Biohydrogen process development on waste sorghum (Sorghum bicolor) leaves: Optimization of saccharification, hydrogen production and preliminary scale up. Int. J. Hydrogen Energy 2016, 41, 12941-12952. [CrossRef]

75. Bouwer, E.J.; McCarty, P.L. Effects of 2-Bromoethanesulfonic Acid and 2-Chloroethanesulfonic Acid on Acetate Utilization in a Continuous-Flow Methanogenic Fixed-Film Column. Appl. Environ. Microbiol. 1983, 45, 1408-1410. [CrossRef]

76. Sparling, R.; Risbey, D.; Poggi-Varaldo, H.M. Hydrogen production from inhibited anaerobic composters. Int. J. Hydrogen Energy 1997, 22, 563-566. [CrossRef]

77. Wang, C.-C.; Chang, C.-W.; Chu, C.-P.; Lee, D.-J.; Chang, B.-V. Sequential production of hydrogen and methane from wastewater sludge using anaerobic fermentation. J. Chin. Inst. Chem. Eng. 2003, 34, 683-687.

78. Kumar, G.; Zhen, G.; Sivagurunathan, P.; Bakonyi, P.; Nemestóthy, N.; Bélafi-Bakó, K.; Kobayashi, T.; Xu, K.-Q. Biogenic H2 production from mixed microalgae biomass: Impact of $\mathrm{pH}$ control and methanogenic inhibitor (BESA) addition. Biofuel Res. J. 2016, 3, 470-474. [CrossRef]

79. Bule, M.V.; Gao, A.H.; Hiscox, B.; Chen, S. Structural Modification of Lignin and Characterization of Pretreated Wheat Straw by Ozonation. J. Agric. Food Chem. 2013, 61, 3916-3925. [CrossRef] [PubMed]

80. Quesada, J.; Rubio, M.; Gómez, D. Ozonation of Lignin Rich Solid Fractions from Corn Stalks. J. Wood Chem. Technol. 1999, 19, 115-137. [CrossRef]

81. Bellido, C.; Bolado, S.; Coca, M.; Lucas, S.; Gonzalez-Benito, G.G.; García-Cubero, M.T. Effect of inhibitors formed during wheat straw pretreatment on ethanol fermentation by Pichia stipitis. Bioresour. Technol. 2011, 102, 10868-10874. [CrossRef]

82. Sun, Y.; Cheng, J. Hydrolysis of lignocellulosic materials for ethanol production: A review. Bioresour. Technol. 2002, 83, 1-11. [CrossRef]

83. Khanal, S.K. Biohydrogen production: Fundamentals, challenges, and operating strategies for enhanced yield. In Anaerobic Biotechnology for Bioenergy Production: Principles and Applications; Khanal, S.K., Ed.; Blackwell Publishing: Hoboken, NJ, USA, 2008; pp. 189-220.

84. Ueki, K.; Ueki, A.; Simogoh, Y. Terminal steps in the anaerobic digestion of municipal sewage sludge: Effects of inhibitors of methanogenesis and sulfate reduction. J. Gen. Appl. Microbiol. 1988, 34, 425-432. [CrossRef]

85. Argun, H.; Kargi, F. Effects of sludge pre-treatment method on bio-hydrogen production by dark fermentation of waste ground wheat. Int. J. Hydrogen Energy 2009, 34, 8543-8548. [CrossRef]

86. Hu, B.; Chen, S. Biological Hydrogen Production Using Chloroform-treated Methanogenic Granules. Appl. Biochem. Biotechnol. 2008, 148, 83-95. [CrossRef] [PubMed]

87. Chidthaisong, A.; Conrad, R. Specificity of chloroform, 2-bromoethanesulfonate and fluoroacetate to inhibit methanogenesis and other anaerobic processes in anoxic rice field soil. Soil Biol. Biochem. 2000, 32, 977-988. [CrossRef]

88. Wang, J.; Wan, W. Comparison of different pretreatment methods for enriching hydrogen-producing bacteria from digested sludge. Int. J. Hydrogen Energy 2008, 33, 2934-2941. [CrossRef] 
89. Luo, G.; Xie, L.; Zou, Z.; Wang, W.; Zhou, Q. Evaluation of pretreatment methods on mixed inoculum for both batch and continuous thermophilic biohydrogen production from cassava stillage. Bioresour. Technol. 2010, 101, 959-964. [CrossRef] [PubMed]

90. Kenealy, W.; Zeikus, J.G. Influence of corrinoid antagonists on methanogen metabolism. J. Bacteriol. 1981, 146, 133-140. [CrossRef]

91. Valdez-Vazquez, I.; Rios-Leal, E.; Munoz-Paez, K.M.; Carmona-Martinez, A.; Poggi-Varaldo, H.M. Effect of inhibition treatment, type of Inocula, and incubation temperature on batch $\mathrm{H}_{2}$ production from organic solid waste. Biotechnol. Bioeng. 2006, 95, 342-349. [CrossRef] [PubMed]

92. Valdez-Vazquez, I.; Sparling, R.; Rinderknecht-Seijas, N.; Risbey, D.; Poggi-Varaldo, H.M. Hydrogen from the anaerobic fermentation of industrial solid waste. Biores. Technol. 2005, 96, 1907-1913. [CrossRef]

93. Vats, S.; Maurya, D.P.; Shaimoon, M.; Agarwal, A.; Negi, S. Develpoment of a microbial consortium for production of blend of enzymes for hydrolysis of agricultural wastes into sugars. J. Sci. Ind. Res. 2013, 72, 585-590.

94. Sánchez, C. Lignocellulosic residues: Biodegradation and bioconversion by fungi. Biotechnol. Adv. 2009, 27, 185-194. [CrossRef]

95. Kumar, P.; Barrett, D.M.; Delwiche, M.J.; Stroeve, P. Methods for pretreatment of lignocellulosic biomass for efficient hydrolysis and biofuel production. Ind. Eng. Chem. Res. 2009, 48, 3713-3729. [CrossRef]

96. Cui, M.; Yuan, Z.; Zhi, X.; Wei, L.; Shen, J. Biohydrogen production from poplar leaves pretreated by different methods using anaerobic mixed bacteria. Int. J. Hydrogen Energy 2010, 35, 4041-4047. [CrossRef]

97. Wong, Y.M.; Wu, T.Y.; Juan, J.C. A review of sustainable hydrogen production using seed sludge via dark fermentation. Renew. Sustain. Energy Rev. 2014, 34, 471-482. [CrossRef]

98. Liu, C.-Z.; Cheng, X.-Y. Improved hydrogen production via thermophilic fermentation of corn stover by microwave-assisted acid pretreatment. Int. J. Hydrogen Energy 2010, 35, 8945-8952. [CrossRef]

99. Assawamongkholsiri, T.; Reungsang, A.; Pattra, S. Effect of acid, heat and combined acid-heat pretreatments of anaerobic sludge on hydrogen production by anaerobic mixed cultures. Int. J. Hydrogen Energy 2013, 38, 6146-6153. [CrossRef]

100. Elbeshbishy, E.; Hafez, H.; Dhar, B.R.; Nakhla, G. Single and combined effect of various pretreatment methods for biohydrogen production from food waste. Int. J. Hydrogen Energy 2011, 36, 11379-11387. [CrossRef]

101. Yang, S.-S.; Guo, W.-Q.; Cao, G.-L.; Zheng, H.-S.; Ren, N.-Q. Simultaneous waste activated sludge disintegration and biological hydrogen production using an ozone/ultrasound pretreatment. Bioresour. Technol. 2012, 124, 347-354. [CrossRef] [PubMed]

102. Zabed, H.M.; Akter, S.; Yun, J.; Zhang, G.; Awad, F.; Qi, X.; Sahu, J.N. Recent advances in biological pretreatment of microalgae and lignocellulosic biomass for biofuel production. Renew. Sustain. Energy Rev. 2019, 105, 105-128. [CrossRef]

103. Fang, J.; Zhan, L.; Ok, Y.S.; Gao, B. Minireview of potential applications of hydrochar derived from hydrothermal carbonization of biomass. J. Ind. Eng. Chem. 2018, 57, 15-21. [CrossRef]

104. Kumar, M.; Oyedun, A.O.; Kumar, A. A review on the current status of various hydrothermal technologies on biomass feedstock. Renew. Sustain. Energy Rev. 2018, 81, 1742-1770. [CrossRef]

105. Zhang, S.; Zhu, X.; Zhou, S.; Shang, H.; Luo, J.; Tsang, D.C. Chapter 15-hydrothermal carbonization for hydrochar production and its application. In Biochar from Biomass and Waste; Ok, Y.S., Tsang, D.C.W., Bolan, N., Novak, J.M., Eds.; Elsevier: Amsterdam, The Netherlands, 2019; pp. 275-294. [CrossRef]

106. Lee, J.; Lee, K.; Sohn, D.; Kim, Y.M.; Park, K.Y. Hydrothermal carbonization of lipid extracted algae for hydrochar production and feasibility of using hydrochar as a solid fuel. Energy 2018, 153, 913-920. [CrossRef]

107. Marin-Batista, J.D.; Villamil, J.A.; Rodriguez, J.J.; Mohedano, A.F.; DE LA Rubia, M.A. Valorization of microalgal biomass by hydrothermal carbonization and anaerobic digestion. Bioresour. Technol. 2019, 274, 395-402. [CrossRef]

108. Sharma, R.; Jasrotia, K.; Singh, N.; Ghosh, P.; Srivastava, S.; Sharma, N.R.; Singh, J.; Kanwar, R.; Kumar, A. A Comprehensive Review on Hydrothermal Carbonization of Biomass and its Applications. Chem. Afr. 2020, 3, 1-19. [CrossRef]

109. Román, S.; Ledesma, B.; Álvarez, A.; Coronella, C.; Qaramaleki, S.V. Suitability of hydrothermal carbonization to convert water hyacinth to added-value products. Renew. Energy 2020, 146, 1649-1658. [CrossRef]

110. Guo, S.; Dong, X.; Wu, T.; Zhu, C. Influence of reaction conditions and feedstock on hydrochar properties. Energy Convers. Manag. 2016, 123, 95-103. [CrossRef]

111. Tasca, A.L.; Puccini, M.; Gori, R.; Corsi, I.; Galletti, A.M.R.; Vitolo, S. Hydrothermal carbonization of sewage sludge: A critical analysis of process severity, hydrochar properties and environmental implications. Waste Manag. 2019, 93, 1-13. [CrossRef] [PubMed]

112. Biswas, B.; Kumar, J.; Bhaskar, T. Advanced hydrothermal liquefaction of biomass for bio-oil production. In Biofuels: Alternative Feedstocks and Conversion Processes for the Production of Liquid and Gaseous Biofuels; Academic Press: Cambridge, MA, USA, 2019; pp. 245-266.

113. Gao, N.; Li, Z.; Quan, C.; Miskolczi, N.; Egedy, A. A new method combining hydrothermal carbonization and mechanical compression in situ for sewage sludge dewatering: Bench-scale verification. J. Anal. Appl. Pyrol. 2019, 139, 187-195. [CrossRef]

114. Daza Serna, L.V.; OrregoAlzate, C.E.; Cardona Alzate, C.A. Supercritical fluids as a green technology for the pretreatment of lignocellulosic biomass. Bioresour. Technol. 2016, 199, 113-120. [CrossRef] [PubMed]

115. Kumar, D.; Singh, B.; Korstad, J. Utilization of lignocellulosic biomass by oleaginous yeast and bacteria for production of biodiesel and renewable diesel. Renew. Sustain. Energy Rev. 2017, 73, 654-671. [CrossRef]

116. Dias, A.L.B.; dos Santos, P.; Martínez, J. Supercritical CO2 technology applied to the production of flavor ester compounds through lipase-catalyzed reaction: A review. J. CO2 Util. 2018, 23, 159-178. [CrossRef]

117. Zhang, J.; Zhou, H.; Liu, D.; Zhao, X. Pretreatment of lignocellulosic biomass for efficient enzymatic saccharification of cellulose. In Lignocellulosic Biomass to Liquid Biofuels; Academic Press: Cambridge, MA, USA, 2019; pp. 17-65. [CrossRef] 
118. Ferreira Santos, A.L.; Fausta Kawase, K.Y.; Vieira Coelho, G.L. Enzymatic saccharification of lignocellulosic materials after treatment with supercritical carbon dioxide. J. Supercrit. Fluids 2011, 56, 277-282. [CrossRef]

119. Rijal, B.; Biersbach, G.; Gibbons, W.R.; Pryor, S.W. Effect of initial particle size and densification on AFEX-pretreated biomass for ethanol production. Appl. Biochem. Biotechnol. 2014, 174, 845-854. [CrossRef]

120. Wang, Q.; Sun, J.; Liu, S.; Gao, L.; Zhou, X.; Wang, D.; Song, K.; Nghiem, L.D. Free ammonia pretreatment improves anaerobic methane generation from algae. Water Res. 2019, 162, 269-275. [CrossRef] [PubMed]

121. Mokomele, T.; Da CostaSousa, L.; Balan, V.; van Rensburg, E.; Dale, B.E.; Görgens, J.F. Incorporating anaerobic co-digestion of steam exploded or ammonia fiber expansion pretreated sugarcane residues with manure into a sugarcane-based bioenergylivestock nexus. Bioresour. Technol. 2019, 272, 326-336. [CrossRef] [PubMed]

122. Zhao, X.; Zhang, L.; Liu, D. Biomass recalcitrance. Part II: Fundamentals of different pre-treatments to increase the enzymatic digestibility of lignocellulose. Biofuels Bioprod. Biorefining 2012, 6, 561-579.

123. Ozgur, E.; Mars, A.E.; Peksel, B.; Louwerse, A.; Yücel, M.; Gündüz, U.; Classen, P.A.M.; Eroğlu, I. Biohydrogen production from beet molasses by sequential dark and photofermentation. Int. J. Hydrogen Energy 2010, 35, 511-517. [CrossRef]

124. Lay, C.-H.; Sen, B.; Chen, C.-C.; Wu, J.-H.; Lee, S.-C.; Lin, C.-Y. Co-fermentation of water hyacinth and beverage wastewater in powder and pellet form for hydrogen production. Bioresour. Technol. 2013, 135, 610-615. [CrossRef]

125. Lari, Z.; Ahmadzadeh, H.; Hosseini, M. Chapter 2-Cell wall disruption: A critical upstream process for biofuel production In Advances in Feedstock Conversion Technologies for Alternative Fuels and Bioproducts; Hosseini, M., Ed.; Woodhead Publishing: Sawston, UK, 2019; pp. 21-35.

126. Brandt, A.; Ray, M.J.; To, T.Q.; Leak, D.J.; Murphy, R.J.; Welton, T. Ionic liquid pretreatment of lignocellulosic biomass with ionic liquid-water mixtures. Green Chem. 2011, 13, 2489-2499. [CrossRef]

127. Abushammala, H.; Mao, J. A Review on the Partial and Complete Dissolution and Fractionation of Wood and Lignocelluloses Using Imidazolium Ionic Liquids. Polymers 2020, 12, 195. [CrossRef]

128. Sun, J.; Shi, J.; Murthy Konda, N.V.S.N.; Campos, D.; Liu, D.; Nemser, S.; Shamshina, J.; Dutta, T.; Berton, P.; Gurau, G.; et al. Efficient dehydration and recovery of ionic liquid after lignocellulosic processing using pervaporation. Biotechnol. Biofuels 2017, 10, 154. [CrossRef]

129. Socha, A.M.; Parthasarathi, R.; Shi, J.; Pattathil, S.; Whyte, D.; Bergeron, M.; George, A.; Tran, K.; Stavila, V.; Venkatachalam, S.; et al. Efficient biomass pretreatment using ionic liquids derived from lignin and hemicellulose. Proc. Natl. Acad. Sci. USA 2014, 111, E3587-E3595. [CrossRef]

130. Park, J.; Shin, H.; Yoo, S.; Zoppe, J.O.; Park, S. Delignification of lignocellulosic biomass and its effect on subsequent enzymatic hydrolysis. BioResources 2015, 10, 2732-2743. [CrossRef]

131. Meng, X.; Parikh, A.; Seemala, B.; Kumar, R.; Pu, Y.; Christopher, P.; Wyman, C.E.; Cai, C.M.; Ragauskas, A.J. Chemical Transformations of Poplar Lignin during Cosolvent Enhanced Lignocellulosic Fractionation Process. ACS Sustain. Chem. Eng. 2018, 6, 8711-8718. [CrossRef]

132. Cai, C.M.; Zhang, T.; Kumar, R.; Wyman, C.E. THF co-solvent enhances hydrocarbon fuel precursor yields from lignocellulosic biomass. Green Chem. 2013, 15, 3140-3145. [CrossRef]

133. Ren, N.-Q.; Zhao, L.; Chen, C.; Guo, W.-Q.; Cao, G.-L. A review on bioconversion of lignocellulosic biomass to $\mathrm{H}_{2}$ : Key challenges and new insights. Bioresour. Technol. 2016, 215, 92-99. [CrossRef]

134. Zhao, L.; Cao, G.-L.; Wang, A.-J.; Ren, H.-Y.; Xu, C.-J.; Ren, N.-Q. Enzymatic saccharification of cornstalk by onsite cellulases produced by Trichoderma viride for enhanced biohydrogen production. GCB Bioenergy 2013, 5, 591-598. [CrossRef]

135. Reginatto, V.; Antônio, R.V. Fermentative hydrogen production from agroindustrial lignocellulosic substrates. Braz. J. Microbiol 2015, 46, 323-335. [CrossRef] [PubMed]

136. Ibrahim, M.F.; Abd-Aziz, S.; Yusoff, M.E.M.; Phang, L.Y.; Hassan, M.A. Simultaneous enzymatic saccharification and ABE fermentation using pretreated oil palm empty fruit bunch as substrate to produce butanol and hydrogen as biofuel. Renew. Energy 2015, 77, 447-455. [CrossRef]

137. Nagarajan, D.; Lee, D.-J.; Chang, J.-S. Recent insights into consolidated bioprocessing for lignocellulosic biohydrogen production. Int. J. Hydrogen Energy 2019, 44, 14362-14379. [CrossRef]

138. Pang, J.; Liu, Z.-Y.; Hao, M.; Zhang, Y.-F.; Qi, Q.-S. An isolated cellulolytic Escherichia coli from bovine rumen produces ethanol and hydrogen from corn straw. Biotechnol. Biofuels 2017, 10, 165. [CrossRef]

139. Islam, S.; Guo, C.; Liu, C.-Z. Enhanced hydrogen and volatile fatty acid production from sweet sorghum stalks by two-steps dark fermentation with dilute acid treatment in between. Int. J. Hydrogen Energy 2018, 43, 659-666. [CrossRef]

140. Rai, P.K.; Singh, S.P.; Asthana, R.K.; Singh, S. Biohydrogen production from sugarcane bagasse by integrating dark- and photo-fermentation. Bioresour. Technol. 2014, 152, 140-146. [CrossRef]

141. Qin, Y.; Li, L.; Wu, J.; Xiao, B.; Hojo, T.; Kubota, K.; Cheng, J.; Li, Y.-Y. Co-production of biohydrogen and biomethane from food waste and paper waste via recirculated two-phase anaerobic digestion process: Bioenergy yields and metabolic distribution. Bioresour. Technol. 2019, 276, 325-334. [CrossRef] [PubMed] 